\title{
FEUPA: UMA REVISTA PRODUZIDA PELA FEDERAÇÃO DOS ESTUDANTES UNIVERSITÁRIOS DE PORTO ALEGRE (RS, 1945/46)
}

\author{
Dilza Porto Gonçalves \\ Comitê da Transversalidade da Seduc/Sedac, Brasil. \\ Patrícia Rodrigues Augusto Carra \\ Colégio Militar de Porto Alegre, Brasil.
}

Resumo

Este artigo divulga parte de uma investigação, ainda em andamento, sobre o impresso estudantil Feupa, revista produzida pelos integrantes da Federação dos Estudantes de Porto Alegre Feupa -, durante a década de 1940. A pesquisa indica que a produção de impressos por estudantes estava relacionada à cultura da época. Os temas abordados pelos estudantes, presentes nas páginas de Feupa, são variados: política, literatura, filosofia, ciências, teatro, assuntos estudantis e problemas relacionados à Universidade de Porto Alegre, que começa a se encaminhar para constituir a atual Universidade Federal do Rio Grande do Sul. Por meio dessas escritas ordinárias, podemos perceber idéias e posicionamentos políticos implícitos nas escolhas dos assuntos, das ilustrações, da distribuição dos textos e imagens no corpo do periódico e explícitos em debates políticos e ideológicos. A análise deste impresso estudantil possibilita o estudo do próprio impresso e da cultura escolar que o envolvia, assim como pode ser norteador de estudos sobre a juventude universitária e o movimento estudantil.

Palavras-chave: impresso estudantil, cultura escolar, movimento estudantil, ensino superior.

\section{FEUPA: A MAGAZINE PRODUCED BY THE FEDERATION OF UNIVERSITY STUDENTS OF PORTO ALEGRE (RS, 1945/46)}

\begin{abstract}
This article presents part of a still ongoing research about the student publication Feupa. It was produced by the members of Student Federation From Porto Alegre - Feupa - during the 1940's. This research indicates that the print production of students was culturally related at that time. The topics discussed by this group in the publication are diverse, among them politics, literature, philosophy, science, theater, and problems related to the University of Porto Alegre, which became later the federal university of Rio Grande do Sul. Trough Feupa, it is possible to perceive implicit
\end{abstract}


political idead and positions when choosing the topics, the illustrations, texts and images. The analysis of these publications allows the study of the cultural background involved. It also guides the research about the youth and the academic field and the student mobilizations.

Key-words: student publication, school culture, student mobilizations.

\title{
FEUPA: UNA REVISTA PRODUCIDA POR LA FEDERAÇÃO DEL ESTUDIANTES UNIVERSITÁRIOS DEL PORTO ALEGRE (RS, 1945/46)
}

\section{Resumen}

Esto artículo divulga parte de una investigación, aunque en desarrollo, acerca de lo impreso del estudiante revista Feupa. Esto impreso fue producido por los miembros de la Federação dos Estudantes de Porto Alegre - Feupa. La pesquisa indica que la producción de los impresos por los estudiantes estaba relacionada a la cultura de la época. Los temas abordados por los estudiantes presentes en las páginas de Feupa son variados. Encontramos textos acerca de política, literatura, filosofía, ciencias, teatro, asuntos de los estudiantes y problemas relacionados a la Universidade de Porto Alegre, que empieza a se encaminar para constituir a la actual Universidade Federal do Rio Grande do Sul. A través de esas escrituras ordinarias, es posible percibir ideas y posicionamientos políticos implícitos en las elecciones de los asuntos, de las ilustraciones, de las distribuciones de los textos e imagenes en lo interior de lo periódico y explícitos en debates políticos e ideológicos. La análisis de estos impresos de los estudiantes posibilita el estudio de los propios impresos e de la cultura escolar que envolvía estos impresos. Así como, puede ser rector en los estudios acerca de la juventud universitaria y acerca de lo movimiento de los estudiantes. Palabras-clave: impreso de los estudiantes, cultura escolar, movimiento de los estudiantes.

\section{FEUPA: UN MAGAZINE PRODUIT PAR LA FEDERATION DES ETUDIANTS UNIVERSITAIRES DE PORTO ALEGRE (RIO GRANDE SUL, 1945/46)}

\begin{abstract}
Résume
Cet article divulgue une partie d'une recherche, encore en cours, concernant l'imprimé scolaire appelé revista Feupa. Cet imprimé a été produit par les membres de la Fédération des Etudiants de Porto Alegre - Feupa -, pendant les années 1940. La recherche signale que la production d'imprimés faits par des étudiants se rapportait à la culture de l'époque. Les sujets traités dans les pages du magazine Feupa sont variés. Nous y voyons des textes sur politique, littérature, philosophie, sciences, théâtre, des sujets concernants aux étudiants et des problèmes liés à I'Université de Porto Alegre, qui commençait, alors, à devenir l'actuelle Université Fédérale du Rio Grande do Sul. Par ces écrits ordinnaires, nous pouvons entrevoir des idées et des positions politiques qui sont implicites dans les choix des sujets, des figures, de l'arrangement des textes et des images au corps du magazine, et qui se montrent explicites dans des débats politiques et idéologiques. L'analyse des ces imprimés scolaires rend possible l'étude des imprimés euxmêmes bien que de la culture scolaire qui les entourait à l'époque. Cet étude peut aussi orienter d'autres études sur la jeunesse universitaire et sur le mouvement des étudiants.

Mots-clé: imprimé scolaire, culture scolaire, mouvement d'étudiants.
\end{abstract}




\section{Introdução}

$\mathrm{O}$ tema deste artigo aborda um impresso estudantil denominado Feupa, produzido durante a década de 40 do século 20, por estudantes universitários de Porto Alegre. Os jovens, que eram editores da revista em questão, vinculavam-se à Universidade de Porto Alegre, instituição de ensino superior relacionada à origem da atual Universidade Federal do Rio Grande do Sul ${ }^{1}$.

O texto que apresentamos é resultado de uma pesquisa em fase inicial, cujo objeto de interesse tem como alvo escritas estudantis e ensino no Brasil. Neste espaço, socializamos uma primeira análise do exemplar de número 4 da revista Feupa, editado no ano de 1946 e referente, também, ao ano de 1945.

Feupa era a sigla que designava a Federação dos Estudantes de Porto Alegre, cuja data de fundação ainda desconhecemos. Os poucos documentos que citam esta associação estudantil, até agora localizadas, não apresentam consenso sobre tal dado.

Segundo informações encontradas no site da Universidade de Santa Maria/RS, a Federação dos Estudantes de Porto Alegre foi fundada no ano de 1934 e o seu primeiro presidente foi o então estudante da Faculdade de Medicina da Universidade de Porto Alegre, José Mariano da Rocha Filho ${ }^{2}$. No entanto, Nicanor Letti, ao escrever sobre as lutas do Centro Acadêmico da Faculdade de Medicina, aponta a fundação da Feupa em 1936. Segundo Letti (2009), no ano de 1934, ano de fundação da Universidade de Porto Alegre, foi criada a Federação Acadêmica de Porto Alegre - Fapa - sendo o estudante Rubens Maciel seu presidente. Em 1936, essa estrutura sofreu alteração e passou ser conhecida como Feupa, tendo como presidente o estudante José Mariano da Rocha Filho $^{3}$.

\footnotetext{
${ }^{1}$ Segundo o site da Universidade Federal do Rio Grande do Sul: "a história da Ufrgs começa com a fundação da Escola de Farmácia e Química, em 1895 e, em seguida, da Escola de Engenharia. [...]. Ainda no século 19, foram fundadas a Faculdade de Medicina de Porto Alegre e a Faculdade de Direito que, em 1900, marcou o início dos cursos humanísticos no Estado. Mas somente em 28 de novembro de 1934, foi criada a Universidade de Porto Alegre, integrada inicialmente pela Escola de Engenharia, com os Institutos de Astronomia, Eletrotécnica e Química Industrial; Faculdade de Medicina, com as Escolas de Odontologia e Farmácia; Faculdade de Direito, com sua Escola de Comércio; Faculdade de Agronomia e Veterinária; Faculdade de Filosofia, Ciências e Letras e pelo Instituto de Belas Artes. O terceiro grande momento de transformação dessa Universidade foi em 1947 quando passou a ser denominada Universidade do Rio Grande do Sul, a Urgs, incorporando as Faculdades de Direito e de Odontologia de Pelotas e a Faculdade de Farmácia de Santa Maria. Posteriormente, essas unidades foram desincorporadas da Urgs, com a criação, da Universidade de Pelotas e da Universidade Federal de Santa Maria. Em dezembro de 1950, a Universidade foi federalizada, passando à esfera administrativa da União. Desde então, a Ufrgs - Universidade Federal do Rio Grande do Sul". Disponível em: http://www. ufrgs.br/ufrgs/a-ufrgs/historico. Acesso em: 14 out. 2012.

2 Informações disponíveis no site: http://w3.ufsm.br/50anos/index.php?canal=o_fundador.

3 José Mariano da Rocha Filho, nascido em Santa Maria em 1915, formou-se em Medicina. Foi líder estudantil e presidente da Federação dos Estudantes Universitários de Porto Alegre. Lecionou Microbiologia na Faculdade de Farmácia de Santa Maria e em 1945 assumiu a direção da entidade. Conduziu o processo de fundação da Universidade Federal de Santa Maria, concretizada em 1967. Informações blog: http://antoniovalsalva.blogspot.com.br/2010/02/o-centro-academico-e-suas-lutas-num4.html e site: http://www.paginadogaucho.com.br/pers/20mais.htm. Acesso em: 14 out., 2012.
} 


\section{A Feupa}

Até o momento, encontramos poucas fontes que fazem referência à Federação dos Estudantes de Porto Alegre - Feupa. Entretanto, o pouco já pesquisado e a produção estudantil encontrada levam-nos a inferir que entendê-la, conhecer o seu funcionamento, idéias, pertencimento, ações, alcance, pode ser de grande auxílio para a compreensão do movimento estudantil, da juventude universitária, das políticas educacionais voltadas para o ensino superior, da história da Universidade Federal do Rio Grande do Sul e do contexto político das décadas de 30 e 40 do século 20.

Segundo Paulo Brossard de Souza Pinto ${ }^{4}$, a Feupa não era a única associação de estudantes existente na Universidade de Porto Alegre na época. Vários cursos tinham associações e publicações, como o Grêmio Universitário Tobias Barreto e o Centro Acadêmico André da Rocha, ambos da Faculdade de Direito. O Centro Acadêmico era facultado para todos os alunos da Faculdade de Direito, enquanto a participação no Grêmio Tobias Barreto só era possível mediante associação na organização. Ao contrário, a Feupa visava a atender os estudantes de todos os cursos presentes na Universidade de Porto Alegre.

\section{A revista Feupa}

Os universitários participantes da Feupa nos legaram os seus impressos: a revista Feupa. Neste periódico registraram muitas de suas inquietudes, feitos, pensamentos, ocorridos. O número que apresentamos foi o único exemplar desta publicação estudantil localizado no Museu da Comunicação Hipólito José da Costa. Nas suas páginas encontramos informações de sua publicação em anos anteriores:

Feupa, sintonizando com esta disposição e, procurando emprestar sua parcela de colaboração aos decisivos problemas do após-guerra, abriu suas colunas ao amplo debate político-social, o qual conscientemente a é lícito desprezar, ao lado doutras secções de expressão do pensamento humano, a continuar assim uma tradição, sedimentada através dos primeiros números. (Feupa, 1945/46 - Pórtico, p. 5)

Paulo Brossard, colaborador nesta investigação, lembra a existência de outros números além do exemplar que localizamos. Onde estão as outras edições da Feupa? A indagação e o fato de, até o momento, ter sido encontrado apenas um exemplar desse periódico sinaliza uma dificuldade comum aos pesquisadores que se dedicam à análise de impressos produzidos por estudantes: a localização. Amaral (2002) tece algumas hipóteses acerca dos motivos que levariam a essa dificuldade:

Em determinadas épocas, por serem considerados subversivos, são inúmeras as histórias de apreensão desses impressos, bem como denúncias de perseguição aos envolvidos em sua elaboração. O caráter não oficial desses periódicos assim como, via de regra, sua irreverência e crítica através, principalmente, de representações satíricas e

\footnotetext{
${ }^{4}$ Paulo Brossard, ministro aposentado do Supremo Tribunal Federal, ex-senador, ministro da Justiça durante o governo de José Sarney, estudante de Direito na época privilegiada por este artigo colaborou com a nossa pesquisa. Sobre a trajetória política de Paulo Brossard há o livro Brossard: 80 anos na história política do Brasil, de Luiz Fernando Valls.
} 
caricaturizadas da sociedade, da escola, de professores e de alunos faz com que não constem no acervo documental das instituições escolares. Quando muito se encontram esquecidos em algumas gavetas dos grêmios estudantis. (Amaral, 2002, p. 123)

As representações sobre a escrita estudantil e sua importância para além do exercício pedagógico sugerem análise sobre as concepções de documento, de memória das instituições e das políticas de preservação. Segundo Pineda (2003),

qualquer instituição, seja educacional ou não, tem a sua política para determinar o que é e qual documento deve ser preservado. Seja por não serem considerados fontes, por não serem considerados pedagógicos ou pela censura política feita aos estudantes, a verdade é que a manutenção de jornais, revistas, enfim, de impressos produzidos por alunos, há pouco começou a ser vista como uma necessária preservação de fontes a respeito da história e da cultura das instituições escolares e da própria sociedade na qual a instituição escolar está inserida. (p. 5)

Podemos considerar que impressos estudantis são pouco preservados em instituições públicas destinadas a tal fim: museus, arquivos, bibliotecas. Entretanto, essas produções culturais compõem um corpus significativo para o estudo da História da Educação e não estão limitadas às contribuições para com o estudo da história das instituições educativas.

Os impressos produzidos por discentes podem ser o próprio objeto de investigação. Analisando-os, temos a possibilidade de observar múltiplas representações sociais presentes na sociedade e que, por extensão, disputam espaço nas instituições escolares. Conseguimos perceber idéias e posicionamentos políticos implícitos nas escolhas dos temas, ilustrações, distribuição dos assuntos no corpo do periódico, assim como dos debates explícitos em suas linhas.

Analisar a imprensa produzida por alunos é, em certa medida, ter como objeto investigativo algo pertencente à ordem do silencioso, dos fazeres e ações ou reações cotidianas:

Este ensaio é dedicado ao homem ordinário. Herói comum. Personagem disseminada. Caminhante inumerável. [...] Este herói anônimo vem de muito longe. É o murmúrio das sociedades. De todo o tempo, anterior aos textos. Nem os espera. Zomba deles. Mas, nas representações escritas, vai progredindo. Pouco a pouco ocupa o centro de nossas cenas científicas. Os projetores abandonaram os atores donos de nomes próprios e de brasões sociais para voltar-se para o coro dos figurantes amontoados dos lados e, depois fixar-se enfim na multidão do público. (Certeau, 2000, p. 57)

O trabalho envolvendo impressos como documento de pesquisa obriga-nos interrogar sobre os seus leitores. Como diria Chartier (1991, p. 181): "o essencial é, portanto, compreender como os mesmos textos, sob formas impressas possivelmente diferentes, podem ser diversamente aprendidos, manipulados, compreendidos".

Os organizadores da revista, na seção Pórtico, informam-nos a respeito do público a quem os escritos eram endereçados: "entregamos este número da Feupa ao julgamento sadio da classe estudantil" (Feupa, 1945/46, p. 6). 
A dedicatória manuscrita com caneta tinta preta por Luisi ${ }^{5}$ para Maria da Graça, na página de abertura, reforça a idéia de sua circulação entre os jovens estudantes universitários da época. Paulo Brossard (2012) recordou que Maria da Graça era sua colega na Faculdade de Direito.

\section{Figura 1}

Capa do n. 4 da revista Feupa.

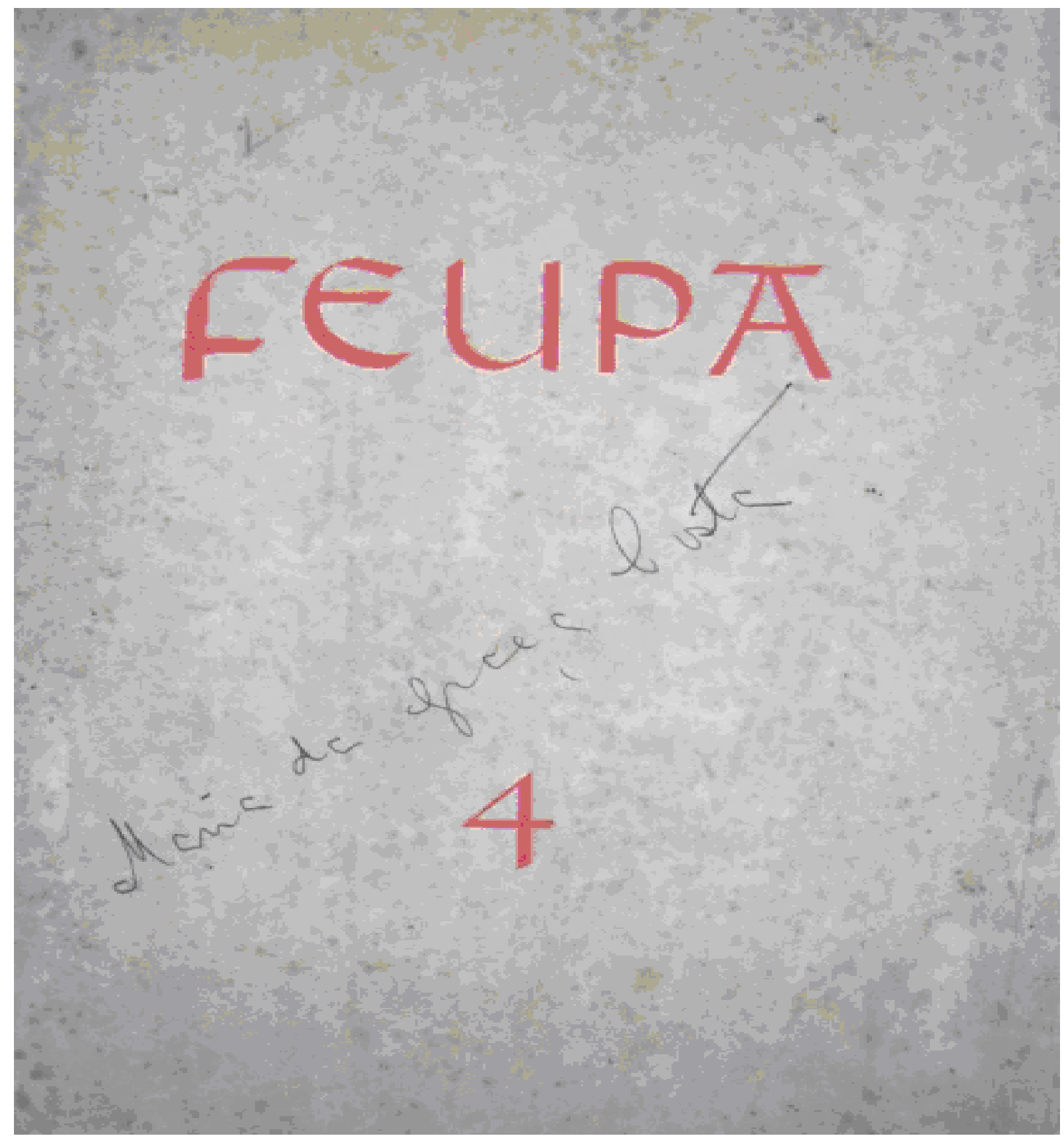

${ }^{5}$ Dedicatória do estudante Luiz V. Luisi, autor do texto Nota sobre o teatro russo, publicado na página 85, para Maria da Graça a quem, pelo que podemos inferir, pertencia o número da revista que analisamos. 


\section{Figura 2}

Imagem da página de abertura do n. 4 da revista Feupa.

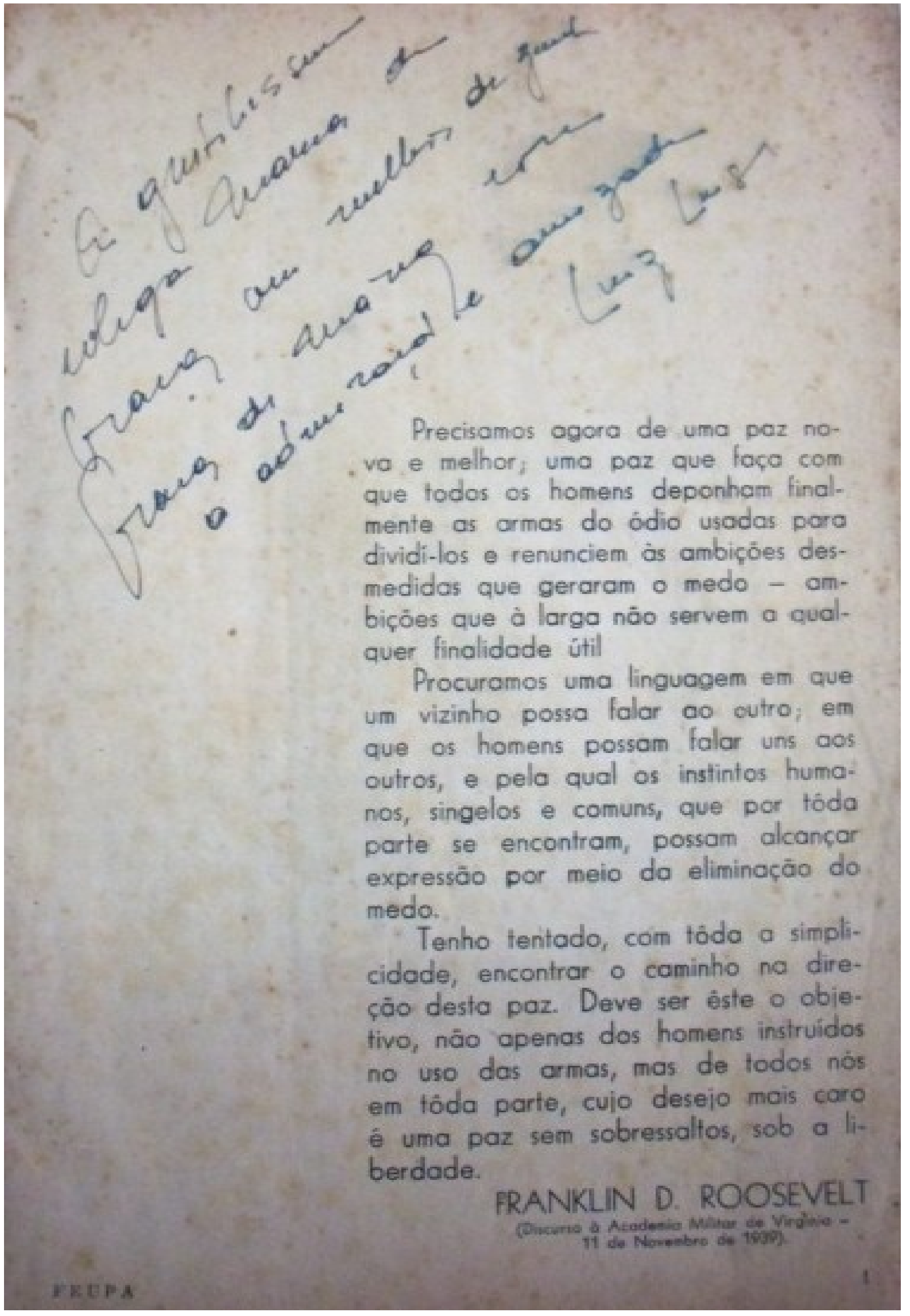


Ainda segundo Paulo Brossard (2012), a revista era distribuída gratuitamente à comunidade universitária.

A reivindicação de maior participação discente nas decisões político-administrativas da Universidade, a defesa da autonomia universitária, o quadro político regional e nacional da época, entre outros aspectos, levam-nos a inferir que esta produção estudantil extrapolava o âmbito discente.

O fim do Estado Novo e a redemocratização estão referidos nas páginas da Feupa:

Assistimos um momento excepcional na vida dos povos. As forças da Democracia retornam vitoriosas dos campos de batalhas, onde esteve em jogo toda a atmosfera da liberdade, e se depõem a depor as armas de morte para empenhar as de construção. [...] Vimos, profundamente dignificados, nossa Pátria contribuir diretamente para o término da Grande Cruzada. Sentimos de maneira especial, a cooperação do estudante brasileiro que, testificando suas conviç̧ões democráticas, não se furtou a participar corporalmente na contenda. Sua atuação não se restringiu todavia, ao front externo. Sob os influxos vivificantes da própria luta, ativados por uma formação moral e política que não se apagará, apesar da longa treva, a nação brasileira em cuja vanguarda marchava a mocidade estudiosa, encaminha-se irresistivelmente para uma reestruturação. Com a alegria que emoldura as grandes vitórias, surgiu o dia dois de dezembro de 1945, data que assinala o início de uma nova fase política do Brasil, bafejada agora pelos estimulantes princípios democráticos. (Feupa, 1945/46, p. 5)

O novo tempo foi expresso pelos estudantes não apenas na seara das idéias. Na prática, os estudantes vivenciavam um período distinto do anterior também no interior da sua associação. A revista Feupa 1945/46 foi produzida pela sua primeira diretoria eleita pelo voto direto e secreto.

Os membros desta diretoria estão representados na fotografia que segue: Miguel Sirangelo Ferro, primeiro tesoureiro, Wenceslau Bermejo, vice-presidente, Álvaro da Cunha, presidente, Benour Bittencourt, primeiro secretário, Paulo Távora, segundo secretário.

Vale ressaltar que a referida revista só foi editada na gestão da segunda diretoria eleita pelo voto direto e secreto. Na página denominada Expediente, os editores de Feupa 1945/46 justificam:

O presente número da Feupa foi preparado na gestão de Álvaro da Cunha. Sua aparição entretanto, registra-se já quando se encontra a frente da Federação o acadêmico Paulo Brossard de Sousa Pinto, eleito em pleito realizado em Maio do corrente ano e, cujo apoio como de seus companheiros de chapa, neste interregno, agradecemos. Este atrazo devese aos trabalhos de impressão que se prolongaram por várias circunstâncias além do prazo previsto. (Feupa, 1945/46, p. 4) 
Figura 3

Primeira diretoria da Feupa eleita pelo voto direto e secreto.

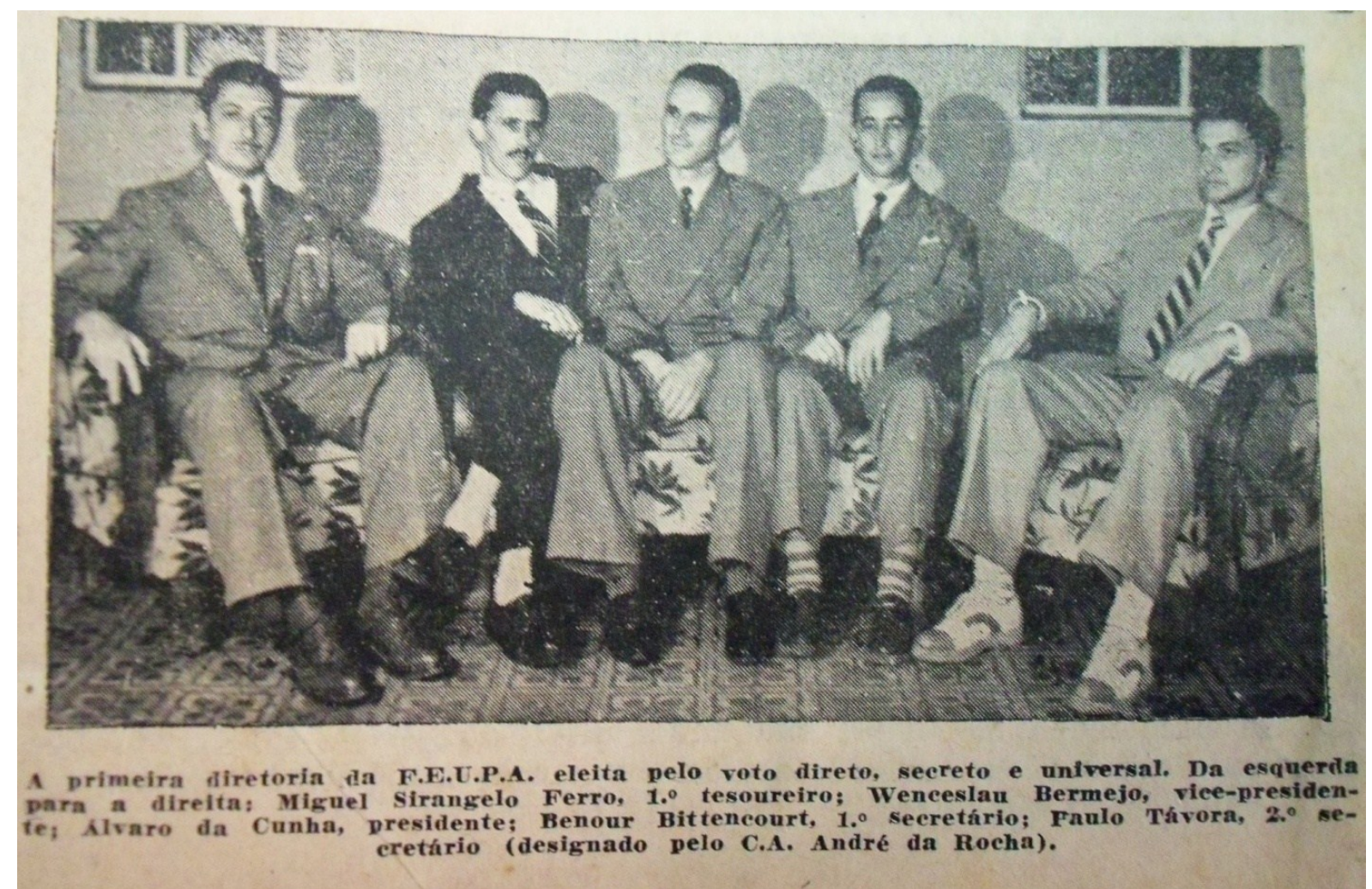

Fonte: Feupa, 1946, p. 133.

As características do pleito, assim como o realce deste pelos editores, estão em consonância com o momento político vivenciado pelo Brasil:

As eleições de 2 de dezembro de 1945 prepararam o terreno para a redemocratização do Brasil. Tendo empossado o seu novo presidente em janeiro de 1946, o país se preparava para refazer a sua Constituição pela quarta vez, desde a queda do Império, em 1889. [...]. O novo Congresso reuniu-se em Assembléia Constituinte e debateu sucessivos projetos constitucionais. Em setembro de 1946 aprovaram uma versão final e o Brasil teve uma nova Constituição. [...] O governo Dutra [...] foi caracterizado por freqüentes apelos por um retorno à tranqüilidade. Dutra gozou de uma lua-de-mel política durante o seu primeiro ano, quando a UDN cooperou com o seu governo nas tarefas imediatas de reconstrução do após-guerra. Não foi senão depois da aprovação da nova Constituição [...] que a política se tornou francamente partidária. (Skidmore, 1982, p. 90)

Conforme dados da revista Feupa, participaram da referida eleição de diretoria os alunos das Faculdades de Agronomia e Veterinária, Direito, Economia e Administração, Engenharia, Filosofia e Medicina da Universidade de Porto Alegre. O maior coeficiente de votos foi atribuído à Faculdade de Engenharia: "representaram 22,2\% do total de votantes" (Feupa, 1945/46, p. 133).

Ao narrar sobre a eleição de sua chapa para a presidência da Feupa, Paulo Brossard (2012) também aborda a repercussão da conjuntura política nacional entre os estudantes: "Eram três candidatos, três correntes [...]. Mas [...] nesse ano, já tinha 
começado a atividade partidária e essas candidaturas, de certa forma, já foram marcadas pelo ambiente, pelo ambiente que recomeçava após 10 anos".

Os anos de 1945 e 1946 foram intensos e marcados por fatores como a pressão para a redemocratização do Brasil, a deposição de Getúlio Vargas, as eleições para a Assembléia Constituinte e para a presidência da República, a promulgação da quinta Constituição brasileira e pelo curto período de legalidade desfrutado pelo Partido Comunista Brasileiro ${ }^{6}$. Imersos e partícipes neste contexto, os estudantes integrantes da Feupa produziram o exemplar do período que temos para análise.

\section{O impresso}

O exemplar de Feupa 1945/46 contém 137 páginas, a maioria impressa em folhas frente e verso de um papel similar ao jornal, porém, de espessura um pouco mais encorpada. Possui tamanho similar ao de um caderno pequeno e poucas imagens: três desenhos e doze fotografias.

As imagens estão concentradas em textos que tratam de assuntos relacionados aos pleitos e demandas importantes aos estudantes, como ilustra o quadro número um.

\section{Quadro 1}

Imagens presentes na revista Feupa.

\begin{tabular}{|c|c|c|}
\hline Página & Imagem & Observação \\
\hline- & $\begin{array}{l}\text { Fotografia de tamanho } \\
\text { médio no centro da } \\
\text { página. }\end{array}$ & Estudante Demócrito de Sousa Filho. \\
\hline 38 & Desenho. & $\begin{array}{l}\text { llustração do conto A carteira representando operário - } \\
\text { Alfredo encontrando uma carteira de dinheiro. }\end{array}$ \\
\hline 102 & $\begin{array}{l}\text { Fotografia de tamanho } \\
\text { pequeno no canto de } \\
\text { página. }\end{array}$ & $\begin{array}{l}\text { Legenda: "Reitor Prof. Armando Câmara quando } \\
\text { expunha o seu ponto de vista". Ilustração texto } \\
\text { "Representação dos Estudantes nos Conselhos } \\
\text { Técnico-Administrativos". }\end{array}$ \\
\hline 104 & $\begin{array}{l}\text { Fotografia de tamanho } \\
\text { pequeno no canto de } \\
\text { página. }\end{array}$ & $\begin{array}{l}\text { Legenda: "Dr. Leovigildo Paiva que prestou sugestivas } \\
\text { declarações". Ilustração texto "Representação dos } \\
\text { Estudantes nos Conselhos Técnico-Administrativos". }\end{array}$ \\
\hline 107 & Desenho. & $\begin{array}{l}\text { Planta "futura cidade universitária". Ilustração texto } \\
\text { "Construção da cidade de Porto Alegre". }\end{array}$ \\
\hline 109 & $\begin{array}{l}\text { Fotografia de tamanho } \\
\text { pequeno no canto de } \\
\text { página. }\end{array}$ & $\begin{array}{l}\text { Legenda: "Dr Luiz Leseigneur de Faria, um dos } \\
\text { idealizadores do Monumento Universitário". Ilustração } \\
\text { texto "Construção da cidade de Porto Alegre". }\end{array}$ \\
\hline 113 & $\begin{array}{l}\text { Fotografia de tamanho } \\
\text { pequeno no canto de } \\
\text { página. }\end{array}$ & $\begin{array}{l}\text { Sem legenda. Representa o dr. Candel de Santos } \\
\text { sendo entrevistado por um estudante integrante da } \\
\text { FEUPA. Ilustra texto: "O Clube Universitário". }\end{array}$ \\
\hline 120 & $\begin{array}{l}\text { Duas fotografias } \\
\text { pequenas, lado a lado no } \\
\text { final da página. }\end{array}$ & $\begin{array}{l}\text { Fotografia (lado esquerdo) - Legenda: "A Secção de } \\
\text { Vendas". Representa dois rapazes frente a uma } \\
\text { estante de livros. }\end{array}$ \\
\hline
\end{tabular}

${ }^{6}$ Em outubro do ano de 1945 o PCB obteve registro eleitoral. Em abril de 1947 o registro eleitoral do Partido foi cancelado pelo Tribunal Superior Eleitoral. O motivo alegado para o cancelamento foi que o Partido seria um instrumento de intervenção soviética no Brasil. No ano de 1948 os parlamentares eleitos pela legenda PCB tiveram seus mandatos cassados e o PCB retornou para um longo período de clandestinidade. Este aspecto é de consideração importante na análise da Feupa e de sua revista devido ao posicionamento político de parte dos seus integrantes e colaboradores. 


\begin{tabular}{|c|l|l|}
\hline & & $\begin{array}{l}\text { Fotografia (lado direito) - Legenda: "A secção de livros } \\
\text { científicos". Representa dois rapazes em pé lendo ou } \\
\text { escolhendo livros rodeados por paredes repletas de } \\
\text { livros (estantes). As fotografias ilustram o texto } \\
\text { "Cooperativa Estudantil". }\end{array}$ \\
\hline 126 & $\begin{array}{l}\text { Fotografia de tamanho } \\
\text { pequeno no canto de } \\
\text { página. }\end{array}$ & $\begin{array}{l}\text { Legenda: "A Casa do Estudante". Ilustra texto "A Casa } \\
\text { do estudante do Rio Gr. do Sul". }\end{array}$ \\
\hline 127 & $\begin{array}{l}\text { Duas fotografias de } \\
\text { tamanho pequeno no } \\
\text { canto de página. }\end{array}$ & $\begin{array}{l}\text { Fotografia canto esquerdo superior - Legenda: "Uma } \\
\text { galeria interna". Fotografia canto direito inferior - } \\
\text { Legenda: "Um ângulo interno da Casa do Estudante". } \\
\text { llustra texto "A Casa do estudante do Rio Gr. do Sul". }\end{array}$ \\
\hline 128 & $\begin{array}{l}\text { Fotografia de tamanho } \\
\text { pequeno no canto } \\
\text { superior esquerdo da } \\
\text { página. }\end{array}$ & $\begin{array}{l}\text { Legenda: "Um aspecto parcial da Biblioteca e Sala de } \\
\text { Reuniões da Casa do Estudante". Ilustra texto "A } \\
\text { Casa do estudante do Rio Gr. do Sul". }\end{array}$ \\
\hline 133 & $\begin{array}{l}\text { Fotografia de tamanho } \\
\text { médio no centro da parte } \\
\text { inferior da página 133. }\end{array}$ & $\begin{array}{l}\text { Legenda: "A primeira diretoria eleita pelo voto direto, } \\
\text { secreto e universal. [...]". Ilustra texto "Eleições na } \\
\text { Feupa". }\end{array}$ \\
\hline $\begin{array}{l}\text { Última } \\
\text { página }\end{array}$ & $\begin{array}{l}\text { Desenho } \\
\text { Alegre. }\end{array}$ \\
\hline
\end{tabular}

A maioria dos textos é de autoria de estudantes. Há escritos não discentes e sobre estes podemos perceber que são frutos de reproduções de textos escolhidos pelos estudantes ou contribuições de pessoas convidadas para colaborar com a edição, como os professores José Salgado Martins e César Saldanha Souza, da Faculdade de Direito, e Candal dos Santos, da Faculdade de Medicina.

O texto do professor José Salgado Martins apresenta um retrospecto sobre o período democrático instaurado em quase toda Europa após a Primeira Guerra Mundial, com exceção da Rússia e da Itália. Referencia a Revolução de 1789 na França e estabelece uma comparação entre os dois momentos históricos. O texto é uma defesa da democracia: "Em poucas palavras, urge se institua ao da democracia política, a democracia social e econômica" (Feupa, 1946, p. 14). Em nota, a redação da Feupa agradece ao professor Salgado Martins e reforça a defesa da democracia social e os seus princípios liberais:

Construa-se de já o pensamento democrático-social para superar as incongruências e as injustiças da sociedade como a temos. Não se despreze jamais, no entanto, as conquistas liberais da democracia. Esta conciliação é possível e será alcançada. Basta que o pensamento a busque com ânimo sincero. (Feupa, 1946, p. 14)

No texto Democracia, Cezar Saldanha de Souza também faz uma reflexão sobre o conceito de democracia. Esclarece sobre a necessidade de fixar um conceito de democracia e explica a etimologia da palavra. Segundo o autor, democracia

é o regime em que se respeita a pessoa humana. É o regime de valorização da pessoa humana, em que o Estado não a absorve tornandose um fim em si mesmo, mas torna-se um do homem realizar sua personalidade. É o regime em que o Estado existe para o indivíduo e para 
serví-lo. [...] só no regime democrático, pode o homem ter uma segurança jurídica, segurança essa que é um dos seus direitos inalienáveis. Só no regime democrático poderá ter essa segurança, pois é nesse regime que está consagrado o dever do Estado de reparar a revogar as medidas que de qualquer forma lesem a liberdade, a propriedade e sua honra. (Feupa, 1946, p. 15-17).

O professor Candal dos Santos, no texto O clube universitário, incentiva à criação de um clube universitário:

Acho magnífica a idéia de fundar-se um Clube Universitário. Já cuidei disso, certa vez, quando Diretor Secretário do Grêmio Náutico Gaúcho. Tenho essa idéia, aliás, há muito tempo, posso evocar para mim o privilégio de exclusividade. (Feupa, 1946, p. 113)

Os conteúdos presentes nos textos estudantis nos permitem inferir as causas importantes aos jovens discentes e parte das idéias e dos autores que admiravam. Como a admiração do estudante Paulo Brossard por Rui Barbosa e Assis Brasil, ambos citados no texto publicado na Feupa 1945/46 e no decorrer da entrevista que nos concedeu em outubro do corrente ano de 2012. No trecho a seguir cita dois de seus autores preferidos:

A combatividade sem par, a autoridade singular, a sabedoria incomum, a desambição, o desinterêsse, o idealismo de Rui Barbosa foram impotentes para derribar a cidadela onde se acastelaram os vícios do regime. As virtudes patriarcais de Assis Brasil, um novo Jefferson, não bastaram para remover as causas do mal que entorpecia a nação. $E$ de ditaduras e revoluções se compõe o diagrama de quarenta anos de presidencialismo. (Feupa, 1946, p. 18)

Brossard (2012) demonstra admiração por estas duas personalidades até o presente. Sobre Rui Barbosa, mantém um acervo com todas suas obras em sua biblioteca particular e sobre Assis Brasil, escreveu uma biografia ${ }^{7}$. Desta forma, podemos inferir que leituras realizadas ao longo da vida estudantil podem marcar a vida profissional e, no caso de Paulo Brossard, sua vida política.

À exceção do texto Teatro do estudante, de Edith Hervé ${ }^{8}$ (Feupa, 1945/46, p. 130 131), todos os escritos são de autoria masculina. A participação feminina nas associações estudantis desta época é assunto raramente levantado. Entretanto, existiam mulheres que freqüentavam a universidade e participavam de diferentes atividades estudantis.

É interessante apontar que, desde os seus primeiros anos, nos seus primeiros congressos, a UNE [União Nacional dos Estudantes] ${ }^{9}$ contou a participação feminina. Esta observação é digna de nota porque os anos de 1940 e 1950, a maioria do alunato de nível superior no Brasil era constituída por homens. Eram eles que ocupavam os bancos das

\footnotetext{
${ }^{7}$ BROSSARD, Paulo. J. F. Assis Brasil. Porto Alegre: EST, 2004.

${ }^{8}$ Sobre o Teatro de Estudante há breve texto disponível para consulta na Enciclopédia Itaú Cultural: <http:// www.itaucultural.org.br/aplicexternas/enciclopedia_teatro/index.cfm?fuseaction=cias_biografia\&cd_verbete =8937>. Acesso em: 11 ago., 2012.

${ }^{9}$ A União Nacional dos Estudantes "foi uma entidade de caráter político e social que reunia um grande número de estudantes pertencentes a diferentes grupos com tendências políticas e ideológicas" (Araujo, 2007, p. 21). Não há consenso sobre a sua data de criação, se 1937 ou se 1938. Sobre a UNE ver Araujo (2007).
} 
faculdades de engenharia, medicina, direito - as mais prestigiadas da época. Nas primeiras décadas do século $X X$ as mulheres brasileiras ainda lutavam pelo direito ao voto e enfrentavam a oposição da família e da sociedade quando decidiam realizar estudos superiores. A resistência ao estudo e à profissionalização das mulheres era ainda muito forte, pois se esperava que elas se dedicassem integralmente ao lar e à família. (Araujo, 2007, p. 74)

A equipe responsável pela edição da revista é, majoritariamente, masculina. A única mulher integrante do grupo era a estudante de medicina Julice Soares Pinto ${ }^{10}$ :

\section{Expediente}

Diretor: Paulo Távora

Secretário: Lélio Carvalho

Sub-Secretário: Paulo Jardim

Redatores: Paulo Hecker Filho, José Augusto Pereira e Atos Gusmão Carneiro. Colaboraram ainda nos trabalhos de revisão e fotografia os acadêmicos Antônio Carapeto Fernandes, Julice Soares Pinto e Sergio Rocha.

Capa: José Lewgoy. (Feupa,1945/46, Expediente)

Contamos 36 universitários envolvidos na produção da revista Feupa e, até o momento, conseguimos identificar o curso de 14: nove so curso de Direito, quatro do curso de Medicina e dois do curso de História Natural. Embora tenhamos identificado mais alunos dos cursos de Medicina e Direito, temos ciência da participação intensa de alunos dos cursos de Engenharia.

\section{Quadro2}

Nomes dos estudantes que escreveram na Feupa com suas respectivas profissões.

\begin{tabular}{|l|l|c|l|l|}
\hline \multicolumn{1}{|c|}{ Estudante } & Faculdade & $\begin{array}{c}\text { Ano da } \\
\text { formatura }\end{array}$ & \multicolumn{1}{|c|}{ Profissão } & Escritos/temas \\
\hline Paulo Távora & Direito & 1949 & $\begin{array}{l}\text { Advogado, ministro } \\
\text { do tribunal de } \\
\text { recursos, professor } \\
\text { universitário }\end{array}$ & Escritor \\
\hline $\begin{array}{l}\text { Paulo Hecker } \\
\text { Filho }\end{array}$ & Direito & & $\begin{array}{l}\text { Várias obras literárias e } \\
\text { de poesia; escreveu para } \\
\text { o Correio do Povo, Zero } \\
\text { Hora e Estado de São } \\
\text { Paulo. }\end{array}$ \\
\hline $\begin{array}{l}\text { Atos de Gusmão } \\
\text { Carneiro }\end{array}$ & Direito & 1949 & $\begin{array}{l}\text { Jurista e professor } \\
\text { universitário }\end{array}$ & $\begin{array}{l}\text { Várias obras sobre } \\
\text { Direito. }\end{array}$ \\
\hline
\end{tabular}

${ }^{10}$ Segundo site http://www.famed.ufrgs.br/site-old/comgradmed/form_med.htm, Julice Soares Pinto formouse em Medicina no ano de 1950. Julice é também mencionada no artigo A cirurgia cardíaca no IC-FUC (Prates, 2001). 


\begin{tabular}{|c|c|c|c|c|}
\hline $\begin{array}{l}\text { Antonio } \\
\text { Carapeto } \\
\text { Fernandes }\end{array}$ & Medicina & 1950 & $\begin{array}{l}\text { Médico e } \\
\text { presidente de } \\
\text { clube esportivo. }\end{array}$ & \\
\hline $\begin{array}{l}\text { Julice Soares } \\
\text { Pinto }\end{array}$ & Medicina & 1950 & Médica. & \\
\hline Sergio Rocha & Medicina & & $\begin{array}{l}\text { Médico } \\
\text { ginecologista. }\end{array}$ & \\
\hline $\begin{array}{l}\text { Paulo Brossard } \\
\text { de Souza Pinto }\end{array}$ & Direito & 1947 & $\begin{array}{l}\text { Professor } \\
\text { universitário, } \\
\text { deputado federal } \\
\text { pelo MDB, ministro } \\
\text { do Tribunal de } \\
\text { Justiça. }\end{array}$ & $\begin{array}{l}\text { Várias obras sobre } \\
\text { Direito, discursos e } \\
\text { biografias. }\end{array}$ \\
\hline $\begin{array}{l}\text { Elmo Pilla } \\
\text { Ribeiro }\end{array}$ & Direito & & $\begin{array}{l}\text { Advogado e } \\
\text { professor } \\
\text { universitário }\end{array}$ & Obras sobre Direito. \\
\hline Eloar Guazelli & Direito & 1948 & $\begin{array}{l}\text { Advogado, } \\
\text { militante do PCB, } \\
\text { deputado federal } \\
\text { pelo MDB. }\end{array}$ & Obras sobre Direito. \\
\hline $\begin{array}{l}\text { Renan Falcão } \\
\text { de Azevedo }\end{array}$ & $\begin{array}{l}\text { História } \\
\text { Natural }\end{array}$ & 1947 & $\begin{array}{l}\text { Professor } \\
\text { universitário e } \\
\text { pesquisador }\end{array}$ & $\begin{array}{l}\text { Obras sobre Biologia e } \\
\text { Genética. }\end{array}$ \\
\hline $\begin{array}{l}\text { Luiz Carlos } \\
\text { Siegmann }\end{array}$ & & & Ambientalista. & \\
\hline Werner Kiel & & & & $\begin{array}{l}\text { Livros sobre química } \\
\text { geral. }\end{array}$ \\
\hline Martin Graudenz & Medicina & & $\begin{array}{l}\text { Trabalhava e fazia } \\
\text { pesquisa em } \\
\text { laboratório de } \\
\text { patologia. }\end{array}$ & \\
\hline Luiz Luisi & Direito & 1947 & $\begin{array}{l}\text { Advogado, jurista e } \\
\text { professor } \\
\text { universitário, } \\
\text { filosofo. }\end{array}$ & $\begin{array}{l}\text { Obras relacionados ao } \\
\text { trabalho. }\end{array}$ \\
\hline $\begin{array}{l}\text { Carlos Galvão } \\
\text { Krebs }\end{array}$ & & & $\begin{array}{l}1^{\circ} \text { presidente do } \\
\text { Departamento de } \\
\text { Tradição e } \\
\text { Folclore, ligado a } \\
\text { Secretaria } \\
\text { Estadual de } \\
\text { Educação. }\end{array}$ & $\begin{array}{l}\text { Livros sobre religião afro- } \\
\text { brasileira e sobre folclore. }\end{array}$ \\
\hline Edith Hervé & Direito & & Atriz e redatora. & $\begin{array}{l}\text { Escreveu na Revista do } \\
\text { Globo. }\end{array}$ \\
\hline Lenine Nequete & Direito & & $\begin{array}{l}\text { Deputado do } \\
\text { partido comunista. } \\
\text { Foi cassado em } \\
1964 .\end{array}$ & \\
\hline
\end{tabular}




\begin{tabular}{|l|l|l|l|l|}
\hline $\begin{array}{l}\text { Antonio } \\
\text { Rodrigues } \\
\text { Cordeiro }\end{array}$ & $\begin{array}{l}\text { História } \\
\text { Natural }\end{array}$ & $1945-$ & $\begin{array}{l}\text { Cientista, professor } \\
\text { universitário. }\end{array}$ & Obras sobre genética. \\
\hline
\end{tabular}

O impresso compõe-se de três partes: Política, Problemas estudantis e Ecos universitários. Contém ainda os seguintes tópicos: Expediente, Abertura, Pórtico, Homenagem e Propaganda da Cooperativa dos Estudantes de Porto Alegre. O quadro a seguir ilustra esta organização.

Quadro 3

Seções e assuntos da revista Feupa.

\begin{tabular}{|c|l|}
\hline Páginas & \multicolumn{1}{|c|}{ Seção } \\
\hline Capa & \multicolumn{1}{|c|}{} \\
\hline Expediente & \multicolumn{1}{|c|}{} \\
\hline 1 & $\begin{array}{l}\text { Página de abertura contendo trecho de discurso de autoria de } \\
\text { Franklin D. Roosevelt datado de 1939. }\end{array}$ \\
\hline 2,3 e 4 & Páginas em branco. \\
\hline 5 e 6 & Pórtico. \\
\hline 7 a 90 & $\begin{array}{l}\text { Página com homenagem ao jovem (á memória) Demócrito de Sousa } \\
\text { Filho }{ }^{11} .\end{array}$ \\
\hline I Parte (Política - Literatura - Sociologia - Filosofia - Divulgação \\
Cientifica - Arte). \\
\hline 117 a 136 & II Parte - Problemas estudantis. \\
\hline I37 & III Parte - Ecos universitários. \\
\hline Proptracapa & $\begin{array}{l}\text { Contém a seguinte indicação: "Impresso nas oficinas gráficas da } \\
\text { Tipografia do Centro S.A. Centro da Boa Imprensa do Rio Grande do } \\
\text { Sul". }\end{array}$ \\
\hline
\end{tabular}

A página de abertura apresenta um trecho do discurso de Franklin Roosevelt proferido na Academia Militar da Virginia, sobre a necessidade da paz. Abaixo reproduzimos parte do texto:

Precisamos agora de uma paz nova e melhor, uma paz que faça com que todos os homens deponham finalmente as armas do ódio usadas para dividi-los e renunciem às ambições desmedidas que geraram o medo (Feupa, 1946, p. 1).

No espaço do que, geralmente, entendemos por editorial, os redatores apresentam um texto intitulado Pórtico, no qual listam os assuntos presentes na revista, exaltam a volta da democracia e a liberdade de pensamento.

Em uma página não numerada, consta uma homenagem ao estudante Demócrito de Sousa Filho, morto em confronto com a polícia durante protestos estudantis em

\footnotetext{
${ }^{11}$ A página traz uma fotografia do jovem seguida do texto: "Á memória de Demócrito de Sousa Filho, nossa homenagem sincera."
} 
Recife/PE. Demócrito de Sousa Filho ${ }^{12}$, estudante de Direito, foi ferido à bala em um disparo da polícia durante um discurso proferido pelo Gilberto Freire realizado em frente à sede do jornal Diário de Pernambuco. A morte desse estudante, ocorrida em 3 de março de 1945, fê-lo símbolo das lutas dos estudantes brasileiros, especialmente nas faculdades de Direito.

Figura 4

Homenagem ao estudante Demócrito de Sousa Filho.

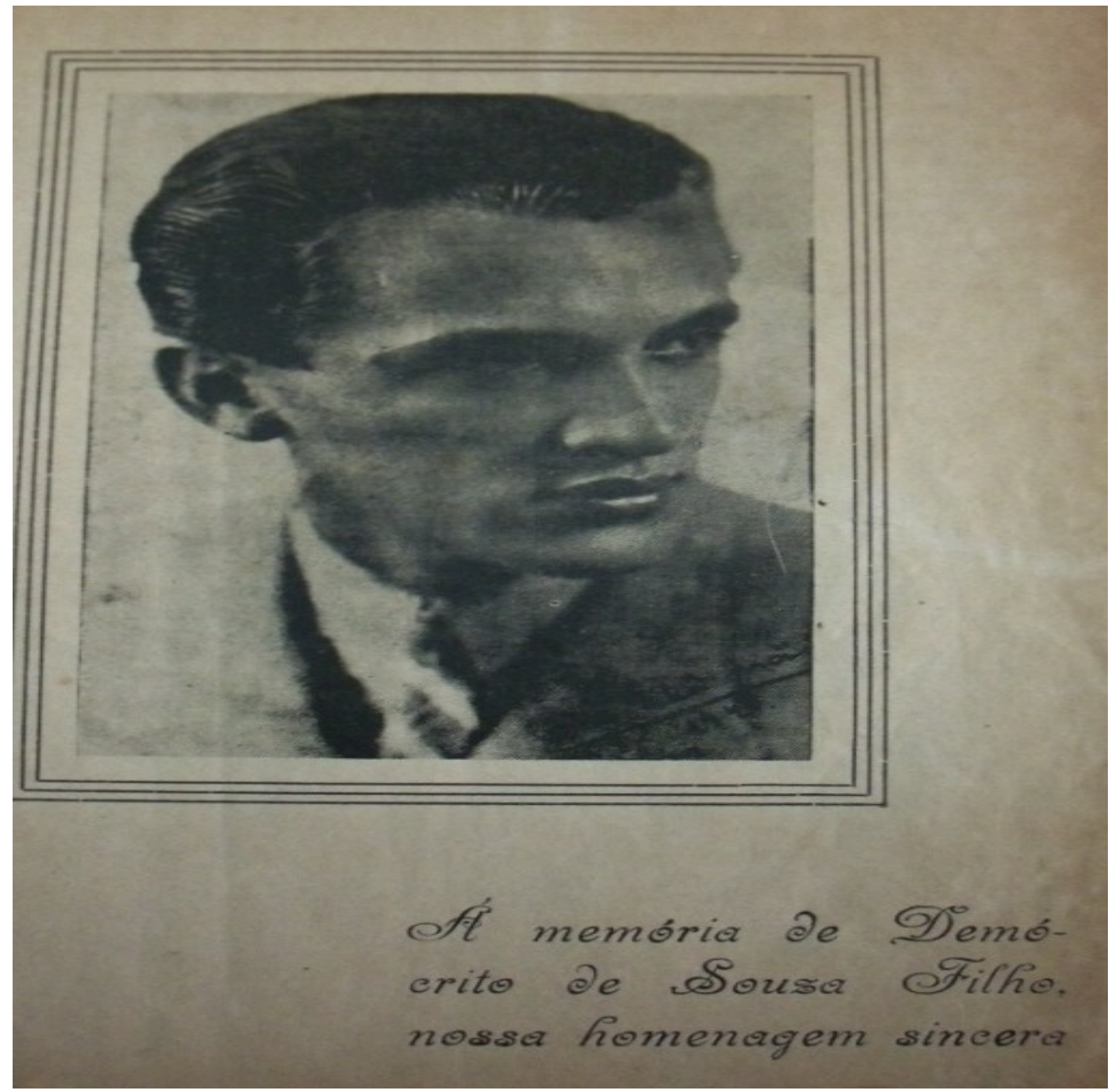

Fonte: Feupa, 1945/46.

12 "Entre 1944 e 1945 aproximando-se o fim da Segunda Guerra Mundial e a certeza da vitória dos aliados, uma parte significativa dos estudantes brasileiros integrou-se na luta pelo restabelecimento do estado de direito e pela anistia. No dia 5 de março de 1945, durante comício realizado em Recife, a favor do candidato oposicionista Eduardo Gomes, um estudante [Demócrito] foi morto pela polícia, atingido por uma bala na testa" (Araujo, 2007, p. 47). 
A página não traz nenhuma explicação sobre o motivo da homenagem. Para os estudantes da época, leitores da Feupa, não havia necessidade de texto além do exposto. A simples referência do nome junto à fotografia já continha todo um simbolismo. $O$ espaço que Ihe foi dedicado na Feupa foi apenas um dos diferentes momentos em que seu nome foi lembrado e relacionado à luta pela redemocratização do país:

Quando aquele rapaz lá do Recife, Demócrito. Por exemplo, quando ele foi assassinado, promovi uma homenagem a ele lá na Faculdade de Direito. Assim protesto. Lembro-me que quando quis fazer, o diretor da faculdade [...] disse: Olha aqui não pode fazer. Eu disse: Então faço no jardim. Ele disse: No jardim pode. (Paulo Brossard, 2012)

São usadas várias citações no corpo da revista, que ocupam espaços entre os diferentes textos. As citações parecem servir para preencher os espaços das páginas não utilizados pelos textos principais e são separadas destes e entre si por recursos gráficos.

No exemplo abaixo, podemos observar uma citação de Condorcet sobre progressão política, na qual o autor reforça os efeitos da instrução elementar para o progresso da humanidade.

Figura 5

Condorcet - progressão política.

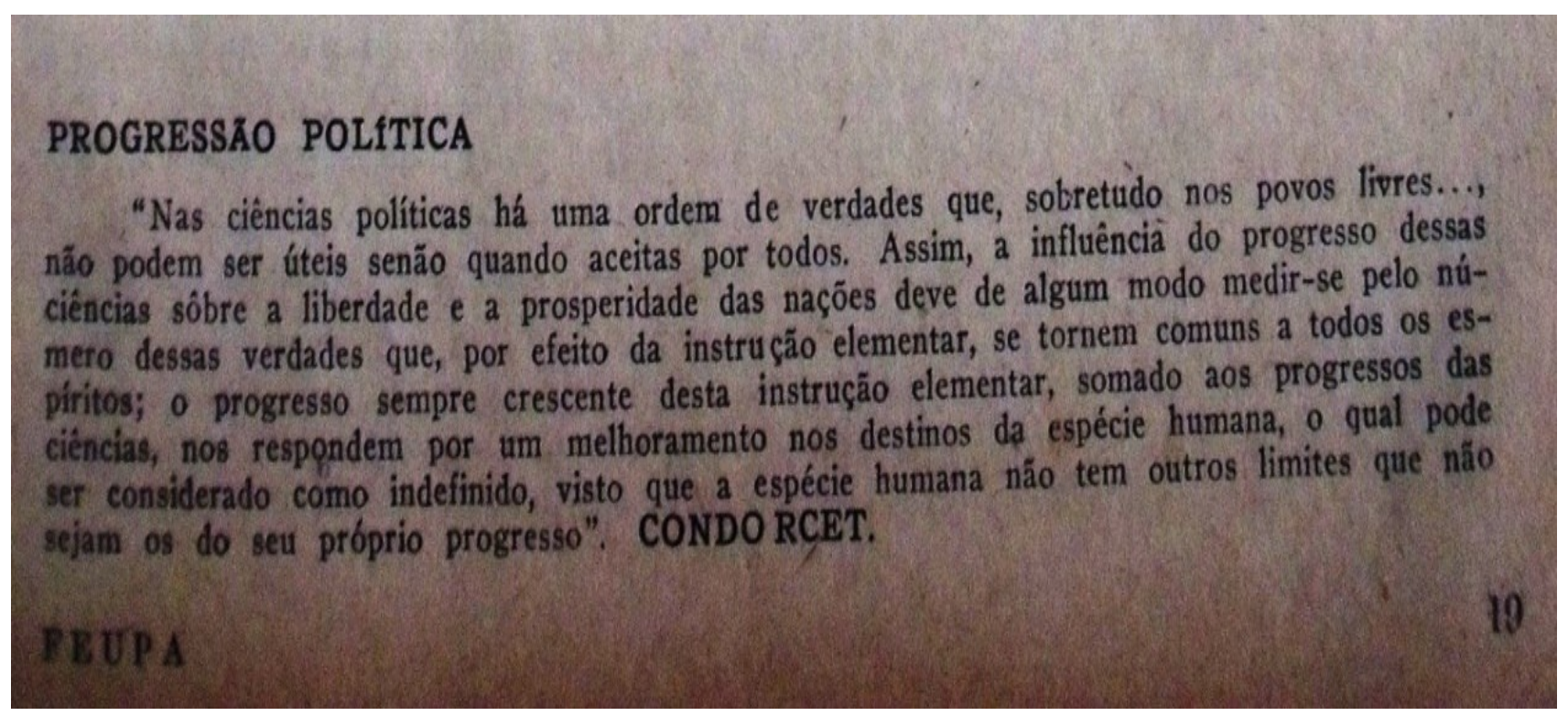

Fonte: Feupa, 1945/46, p. 19

Além de Condorcet, outros autores de renome nacional ou internacional tiveram trechos de seus textos citados na Feupa, tais como: Rooselvelt, Jacques Maritain, James H. Robinson, Friedrich Hayek, Pitirin Sorokin, Giovanni Papini, Monteiro Lobato, Gorki, Graça Aranha, Raul Pompéia, Georges Duhamel, Rudolf Steiner, Walter Lippman, David Hume, Tristão de Athayde, Conde de Keiserling, Luigui Pirandello, Faublas, B. Ponce, Karl von Frisch, Omar Khayyan, Ernest Trattner, Alfred Adler, Ibsen, Mahatma Gandhi, Ernest Renan, Henri Thomas, Frederico Garcia Lorca, Barnave, Michael Gold e R. P. 
Malagrida. Com duas ou mais citações temos: Marquês de Maricá, Carmichael, Flaubert, Oscar Wilde, Charles Morgan, James Joyce e Goethe.

A primeira parte da revista é denominada I Parte e está subdividida nos seguintes títulos: Política, Literatura, Sociologia, Filosofia, Divulgação Científica e Arte.

O título Política contém textos diversificados e conta com a autoria de três alunos e de dois professores. O quadro abaixo nos auxilia a visualizar o conjunto I Parte - Política.

Quadro 4

Revista Feupa - I Parte - Política.

\begin{tabular}{|c|c|c|c|}
\hline Página & Autor & Título & Assunto \\
\hline 7 & $\begin{array}{l}\text { Direção: } \\
\text { Paulo Hecker } \\
\text { Filho }\end{array}$ & I Parte & Sumário da seção. \\
\hline $9 / 12$ & & $\begin{array}{l}\text { Transcrição do Ato de } \\
\text { Chapultepec }\end{array}$ & $\begin{array}{l}\text { Declaração sobre Assistência } \\
\text { Recíproca e Solidariedade Americana - } \\
3 \text { de março de } 1945 \text {. Sobre o acordo } \\
\text { afirmado entre os países representados } \\
\text { na Conferência Interamericana sobre } \\
\text { os Problemas da Guerra e da Paz, logo } \\
\text { após a II Guerra Mundial. Acordo com } \\
\text { princípios liberais. }\end{array}$ \\
\hline $13 / 14$ & $\begin{array}{l}\text { Dr. José } \\
\text { Salgado Martins }\end{array}$ & $\begin{array}{l}\text { Revisão do Conceito de } \\
\text { Democracia }\end{array}$ & $\begin{array}{l}\text { Retrospectiva sobre as democracias na } \\
\text { Europa. Faz uma revisão do conceito } \\
\text { de democracia no pós-guerra. }\end{array}$ \\
\hline $15 / 17$ & $\begin{array}{l}\text { Dr. Cezar } \\
\text { Saldanha de } \\
\text { Souza } \\
\text { Professor de } \\
\text { Direito } \\
\end{array}$ & Democracia & $\begin{array}{l}\text { Reflexão sobre conceito de democracia } \\
\text { associando-o aos direitos dos cidadãos } \\
\text { e à liberdade. }\end{array}$ \\
\hline 17 & & $\begin{array}{l}\text { [Citação] } \\
\text { O Defeito }\end{array}$ & $\begin{array}{l}\text { Trecho de texto versando sobre } \\
\text { interesses da indústria sobrepostos aos } \\
\text { interesses humanos. } \\
\text { Identificado como "Citação de um dos } \\
\text { mais brilhantes economistas ingleses } \\
\text { modernos - pág. } 146 \text { "A formação da } \\
\text { mentalidade"”. }\end{array}$ \\
\hline 17 & & $\begin{array}{l}\text { [Citação] } \\
\text { Esperança } \\
\text { Indesmentida }\end{array}$ & $\begin{array}{l}\text { Citação de trecho de texto de autoria } \\
\text { de Jacques Maritain. }\end{array}$ \\
\hline $18 / 19$ & $\begin{array}{l}\text { Paulo Brossard } \\
\text { de Souza Pinto } \\
\text { (estudante) }\end{array}$ & $\begin{array}{l}\text { A Constituinte e a Lição } \\
\text { Republicana }\end{array}$ & $\begin{array}{l}\text { Retrospecto da República } \\
\text { Presidencialista no Brasil. Enaltece Rui } \\
\text { Barbosa. Defende o parlamentarismo. }\end{array}$ \\
\hline 19 & & $\begin{array}{l}\text { [Citação] } \\
\text { Progressão política }\end{array}$ & $\begin{array}{l}\text { Citação trecho de texto atribuído a } \\
\text { Condorcet. }\end{array}$ \\
\hline $20 / 21$ & $\begin{array}{l}\text { Dante Gabriel } \\
\text { Guimaraens } \\
\text { (estudante) }\end{array}$ & $\begin{array}{l}\text { Função Política das } \\
\text { agremiações estudantis }\end{array}$ & $\begin{array}{l}\text { Critíca a política direitista aplicada no } \\
\text { Brasil, associada ao medo do } \\
\text { comunismo. Associa democracia ao } \\
\text { liberalismo, mas enfatiza que os } \\
\text { cidadãos devem participar da coisa } \\
\text { pública. Sugere que as agremiações }\end{array}$ \\
\hline
\end{tabular}




\begin{tabular}{|c|l|l|l|}
\hline & & & $\begin{array}{l}\text { estudantis devem fazer propaganda da } \\
\text { democracia. }\end{array}$ \\
\hline 21 & & [Citação] & $\begin{array}{l}\text { Trecho de texto atribuído a James H. } \\
\text { Robinson. }\end{array}$ \\
\hline 21 & & $\begin{array}{l}\text { [Citação] } \\
\text { Quem, a quem? }\end{array}$ & $\begin{array}{l}\text { Citação acompanhada de indicação de } \\
\text { leitura do livro 'O Caminho da Servidão' } \\
\text { de Friedrich Hayek. }\end{array}$ \\
\hline 22 / 24 & $\begin{array}{l}\text { Paulo Hecker } \\
\text { Filho } \\
\text { (estudante) }\end{array}$ & $\begin{array}{l}\text { Sobre a necessidade de } \\
\text { ser livre }\end{array}$ & $\begin{array}{l}\text { Sobre política, no entanto, faz crítica as } \\
\text { teorias anti-liberais, como o comunismo } \\
\text { e o fascismo. Defende a liberdade } \\
\text { individual. }\end{array}$ \\
\hline 24 & & $\begin{array}{l}\text { Citação trecho texto de Pitirim A. } \\
\text { Sorokin. }\end{array}$ \\
\hline
\end{tabular}

Embora a maioria dos textos apresente cunho liberal, Paulo Brossard de Souza Pinto (2012) enfatiza que a revista não tinha uma linha ideológica definida e que eram aceitos textos de diferentes correntes ideológicas.

O conjunto I Parte - Literatura é composto por cinco resenhas, um conto, quatro poesias, indicação de obras para leitura de oito autores e quatro citações. $\mathrm{O}$ quadro de número 5 permite que tenhamos uma idéia desta seção da revista.

Quadro 5

Revista Feupa - I Parte - Literatura.

\begin{tabular}{|c|l|l|l|}
\hline Página & \multicolumn{1}{|c|}{ Autor } & \multicolumn{1}{|c|}{ Título } & \multicolumn{1}{c|}{ Observação } \\
\hline 25 & $\begin{array}{l}\text { Direção: José } \\
\text { Augusto Pereira }\end{array}$ & $\begin{array}{l}\text { O romance de uma } \\
\text { descoberta }\end{array}$ & $\begin{array}{l}\text { Resenha sobre o livro de Gustavo } \\
\text { Corção "A descoberta do outro". }\end{array}$ \\
\hline $27 / 29$ & Wilson Chagas & A montanha & $\begin{array}{l}\text { Resenha (pequeno texto) sobre o } \\
\text { Sermão da Montanha (texto presente } \\
\text { no Novo Testamento, livro da Bíblia). }\end{array}$ \\
\hline 29 & Giovanni Papini & [citação] & $\begin{array}{l}\text { Citação antecedida pela seguinte nota: } \\
\text { "Talvez este seja o fragmento } \\
\text { primordial da obra de Monteiro } \\
\text { Lobato".Cita parte do texto Urupês de } \\
\text { Monteiro Lobato: "O caboclo é soturno". }\end{array}$ \\
\hline $30 / 31$ & Elmo Pila Ribeiro & $\begin{array}{l}\text { A propósito de uma } \\
\text { novela }\end{array}$ & $\begin{array}{l}\text { Resenha sobre o livro "Os Ratos", de } \\
\text { Dionélio Machado. }\end{array}$ \\
\hline 31 & [citação] & $\begin{array}{l}\text { Citação frase autoria de Carmichel: } \\
\text { "Não me importo que as coisa que eu } \\
\text { faça ou escreva sejam". }\end{array}$ \\
\hline $32 / 33$ & José Lamego & $\begin{array}{l}\text { Um romance e muitos } \\
\text { outros }\end{array}$ & $\begin{array}{l}\text { Resenha sobre o livro “Capricornius" de } \\
\text { Ovídio Chaves. }\end{array}$ \\
\hline 33 & Gorki & $\begin{array}{l}\text { Citação trecho de texto de Gorkín } \\
\text { antecedida de rápido elogio ao autor: } \\
\text { "perfeito no descritivo-maravilhoso". }\end{array}$ \\
\hline
\end{tabular}

${ }^{13}$ Máximo Gorki: um dos expoentes da literatura russa do século 19, considerado criador da literatura proletária. 


\begin{tabular}{|c|c|c|c|}
\hline 33 & & [citação] & $\begin{array}{l}\text { Citação frase Marquês de Maricá: “A } \\
\text { fantasia é a lanterna mágica de nossa } \\
\text { alma”. }\end{array}$ \\
\hline $34 / 35$ & Gastão Nogueira & Poesias & Sem títulos. \\
\hline 36 & Claudio Furtado & Poesias & Títulos: Nas Ondas e Num álbum. \\
\hline $38 / 40$ & $\begin{array}{l}\text { Carlos de Azevedo } \\
\text { Legori }\end{array}$ & A Carteira & $\begin{array}{l}\text { Conto sobre um homem que encontrou } \\
\text { uma carteira com dinheiro e devolveu a } \\
\text { polícia, no entanto foi acusado de } \\
\text { roubo de parte do dinheiro que havia } \\
\text { na referida carteira. }\end{array}$ \\
\hline 40 & N.R. & & Análise do texto A Carteira. \\
\hline $41 / 44$ & $\begin{array}{l}\text { José Augusto } \\
\text { Pereira }\end{array}$ & $\begin{array}{l}\text { Linguagem } \\
\text { intraduzivel }\end{array}$ & $\begin{array}{l}\text { Resenha sobre a tradução de } \\
\text { Baudelaire realizada por Guilherme de } \\
\text { Almeida (elogios). }\end{array}$ \\
\hline 44 & & & Citação dizeres de Graça Aranha \\
\hline $45 / 47$ & Paulo Hecker Filho & $\begin{array}{l}\text { Notícias de livros: } \\
\text { páginas onde os } \\
\text { editores indicam livros } \\
\text { aos leitores. }\end{array}$ & $\begin{array}{l}\text { Obras e autores indicados: Poemas - } \\
\text { de Nilson Bertoline; Urupês - de } \\
\text { Monteiro Lobato; Contos da estepe - de } \\
\text { Máximo Gorki; Fruta estranha - de } \\
\text { Lilian Smith; Judeus sem dinheiro - de } \\
\text { Michael Gold; Seis dramas - De Henrik } \\
\text { Ibsen; O Ateneu - Raul de Pompéia; } \\
\text { obras de Georges Duhamel. }\end{array}$ \\
\hline
\end{tabular}

É possível observar na seção sobre literatura, no texto de Paulo Hecker Filho sobre indicações de livros, que a maioria deles tem citações ao longo da revista.

A seção I Parte - Sociologia contém apenas dois textos, conforme indicado no quadro que segue.

Quadro 6

Revista Feupa - I Parte - Sociologia.

\begin{tabular}{|c|l|l|l|}
\hline Página & \multicolumn{1}{|c|}{ Autor } & \multicolumn{1}{|c|}{ Título } & \multicolumn{1}{c|}{ Assunto } \\
\hline 49 & $\begin{array}{l}\text { Direção: } \\
\text { AntonioCarapeto } \\
\text { Fernandes }\end{array}$ & Sociologia & Sumário. \\
\hline $51 / 53$ & Rubens Sant'Anna & $\begin{array}{l}\text { O gaúcho da legenda } \\
\text { e homem do presente }\end{array}$ & Sobre o termo gaúcho. \\
\hline 53 & & [citação] & Frase autoria de Flabert. \\
\hline $54 / 55$ & Lenine Nequete & $\begin{array}{l}\text { A Santa Família } \\
\text { (resumo dos estudos } \\
\text { sob este título) }\end{array}$ & $\begin{array}{l}\text { Neste texto são lembrados vários } \\
\text { autores: Schmidt, Koppers, Gemeli, } \\
\text { LucienFebvre, Fr. Picard, Edoard } \\
\text { Meyer, Malinowski, Cuvillier. }\end{array}$ \\
\hline 55 & & [citação] & Parágrafo autoria de Rudolf Steiner. \\
\hline 55 & & [citação] & Frase autoria do Marquês de Maricá. \\
\hline
\end{tabular}

Na seção intitulada I Parte -Filosofia, encontramos quatro citações e dois textos: Aspectos do marxismo e Concepção subjetiva do sentido da vida. 
Quadro 7

Revista Feupa - I Parte - Filosofia.

\begin{tabular}{|c|l|l|l|}
\hline Página & \multicolumn{1}{|c|}{ Autor } & \multicolumn{1}{|c|}{ Título } & \multicolumn{1}{c|}{ Assunto } \\
\hline 57 & $\begin{array}{l}\text { Direção: Atos de } \\
\text { Gusmão }\end{array}$ & Filosofia & Sumário. \\
\hline 59 /65 & $\begin{array}{l}\text { Antonio Pinheiro } \\
\text { Machado Neto; } \\
\text { EloarGuazelli; } \\
\text { Renan Falcão de } \\
\text { Azevedo }\end{array}$ & $\begin{array}{l}\text { Aspectos do } \\
\text { Marxismo }\end{array}$ & $\begin{array}{l}\text { Os três autores apresentam o } \\
\text { marxismo buscando a origem das } \\
\text { ideias que o norteiam e explicando as } \\
\text { suas fases. }\end{array}$ \\
\hline 65 & & $\begin{array}{l}\text { [citação] } \\
\text { O século do homem } \\
\text { do povo }\end{array}$ & $\begin{array}{l}\text { Citação trecho texto de Walter } \\
\text { Lippmann. }\end{array}$ \\
\hline 65 & [citação] & $\begin{array}{l}\text { Tema liberdade. Citação de frase de } \\
\text { David Hume. }\end{array}$ \\
\hline $66 / 67$ & $\begin{array}{l}\text { Guilherme Flores } \\
\text { da Cunha }\end{array}$ & $\begin{array}{l}\text { Concepção subjetiva } \\
\text { do sentido da vida }\end{array}$ & $\begin{array}{l}\text { Trata como as diferentes teorias e } \\
\text { religiões buscam o sentido a vida. }\end{array}$ \\
\hline 67 & & $\begin{array}{l}\text { [citação] } \\
\text { As três filosofias }\end{array}$ & $\begin{array}{l}\text { Citação frase autoria de Tristão de } \\
\text { Athayde. }\end{array}$ \\
\hline 67 & [citação] & $\begin{array}{l}\text { Citação frase de autoria do Conde de } \\
\text { Keiserling. }\end{array}$ \\
\hline
\end{tabular}

O texto Aspectos do marxismo é de autoria de estudantes comunistas. Durante a entrevista, Paulo Brossard (2012) lembrou colegas ligados ao Partido Comunista: Antonio Pinheiro Machado Neto, Eloar Guazelli e Renan Falcão de Azevedo.

O quadro de número 8 expõe a seção Divulgação científica, que contém três textos e uma lista de títulos de revistas norte-americanas encomendadas pela Universidade ${ }^{14}$.

Quadro 8

Revista Feupa - I Parte - Divulgação científica.

\begin{tabular}{|c|l|l|l|}
\hline Página & \multicolumn{1}{|c|}{ Autor } & \multicolumn{1}{|c|}{ Título } & \multicolumn{1}{c|}{ Assunto } \\
\hline 69 & $\begin{array}{l}\text { Direção: Antonio } \\
\text { Rodrigues Cordeiro }\end{array}$ & Divulgação científica & Sumário. \\
\hline $71 / 72$ & $\begin{array}{l}\text { Luiz Carlos } \\
\text { Meneghini }\end{array}$ & $\begin{array}{l}\text { Amanhã a Ciência o } \\
\text { Esclarecerá }\end{array}$ & $\begin{array}{l}\text { Sobre o avanço e a importância da } \\
\text { ciência. }\end{array}$ \\
\hline 72 & & $\begin{array}{l}\text { [citação] } \\
\text { Olha }\end{array}$ & $\begin{array}{l}\text { Citação de trecho do livro O romance } \\
\text { da biologia, de Karl von Frisch. }\end{array}$ \\
\hline
\end{tabular}

14 Matemática: National Mathematic Magazine, Mathematical Review, Mathematics Teacher, Bulletin of American Mathematical society, Bulletin of Mathematical Biophysics. Física: Physical Review, Journal of Mathematics and Physics, Journal of the Franklin Institute, Journal of Scientific Instruments, American Journal of Science, Scientific Montly, American Journal of Physics. Química: Journal of American Chemical Society with Chemical Abstracts, Journal of Physical Chemistry, Archives of Biochemistry, Journal of Biological Chemistry, Journal of organic chemistry, Journal of Chemical Physical, Journal of Chemical Education. Biologia: Ecology, Genetics, Journal of Herdity, Science, Annals of Aplied Biology, Lancet (estes dois da Inglaterra), Biological Abstracts. Zoologia: Journal of Experimental Zoology, Journal of Entomology and Zoology, Botânica: American Journal of Botany, Botanicat Gazette, Botanical Review, Chronica Botanica. Geografia: Journal of Geography, Geographical Magazine, Geophysics, Geographical Review (Feupa, 1945/46, p. 79). 


\begin{tabular}{|c|c|c|c|}
\hline $73 / 74$ & $\begin{array}{l}\text { Arno Rubem } \\
\text { Siegmann e } \\
\text { Werner Kiel }\end{array}$ & $\begin{array}{l}\text { Subsídios a uma nova } \\
\text { filosofia da Ciência }\end{array}$ & Sobre a ciência. \\
\hline 74 & & [citação] & $\begin{array}{l}\text { Citação frase de autoria do marquês de } \\
\text { Maricá. }\end{array}$ \\
\hline $75 / 78$ & $\begin{array}{l}\text { Antonio Rodrigues } \\
\text { Cordeiro }\end{array}$ & $\begin{array}{l}\text { A importância da } \\
\text { ciência } \\
\text { Alguns aspectos da } \\
\text { biologia atual, sua } \\
\text { utilidade e sua } \\
\text { influência na vida do } \\
\text { homem. }\end{array}$ & $\begin{array}{l}\text { A ciência, suas descobertas, seus } \\
\text { estudos e importância na vida humana. }\end{array}$ \\
\hline 78 & & $\begin{array}{l}\text { [citação] } \\
\text { O valor da hipotese }\end{array}$ & $\begin{array}{l}\text { Citação frase de autoria de Ernest } \\
\text { Trattner. }\end{array}$ \\
\hline 78 & & $\begin{array}{l}\text { [citação] } \\
\text { Pose }\end{array}$ & $\begin{array}{l}\text { Citação frase de autoria de Alfred } \\
\text { Adler. }\end{array}$ \\
\hline 79 & & $\begin{array}{l}\text { Revistas cientificas } \\
\text { norte-americanas }\end{array}$ & $\begin{array}{l}\text { Lista das revistas científicas } \\
\text { encomendadas pela Universidade. }\end{array}$ \\
\hline
\end{tabular}

A primeira parte da revista é concluída com a seção de Arte, apresentada no quadro que segue.

\section{Quadro 9}

Revista Feupa, primeira parte: arte.

\begin{tabular}{|c|l|l|l|}
\hline Página & \multicolumn{1}{|c|}{ Autor } & \multicolumn{1}{|c|}{ Título } & \multicolumn{1}{c|}{ Assunto } \\
\hline 81 & $\begin{array}{l}\text { Direção: Martin } \\
\text { Graudenz }\end{array}$ & Arte & Sumário. \\
\hline $83 /$ & Guaracy & $\begin{array}{l}\text { Educação musical da } \\
\text { juventude }\end{array}$ & $\begin{array}{l}\text { Aconselha a educação musical e critica } \\
\text { a evolução do rádio, pois as pessoas } \\
\text { não sentem a alma do artista. } \\
\text { Aconselha a organização de pequenas } \\
\text { orquestras de estudantes. }\end{array}$ \\
\hline 85 & Luiz Luisi & $\begin{array}{l}\text { Nota Sobre teatro } \\
\text { Russo }\end{array}$ & $\begin{array}{l}\text { Conceitua as duas expressões do } \\
\text { teatro russo: Stalmavski e Mayerbold. }\end{array}$ \\
\hline 85 & & [citação] & Versos de autoria de Wilde \\
\hline $86 / 88$ & Martin Graudenz & $\begin{array}{l}\text { Miguel Angelo através } \\
\text { de suas poesias }\end{array}$ & $\begin{array}{l}\text { Analisa as poesias de Miguel Angelo e } \\
\text { as caracteriza impregnadas de } \\
\text { sofrimento, dor e amor. }\end{array}$ \\
\hline 88 & & $\begin{array}{l}\text { Citação texto de autoria de Charles } \\
\text { [citação] } \\
\text { Como Nicodemo } \\
\text { esculpiu a imagem de } \\
\text { Cristo }\end{array}$ & Morgan. \\
\hline 88 & & $\begin{array}{l}\text { [citação] } \\
\text { O cônsolo de lbsen }\end{array}$ & Citação sem nomear autoria. \\
\hline
\end{tabular}

No espaço da revista denominado segunda parte, os estudantes abordaram o que classificaram como problemas estudantis, apresentados no quadro de número 10. 
Quadro 10

Revista Feupa, segunda parte: problemas estudantis.

\begin{tabular}{|c|c|c|c|}
\hline Página & Autor & Título & Assunto \\
\hline $91 / 97$ & & Problemas estudantis & Sumário \\
\hline $93 / 97$ & Alvaro Cunha & $\begin{array}{l}\text { A Universidade de } \\
\text { Porto Alegre e o } \\
\text { Instituto de Belas } \\
\text { Artes. }\end{array}$ & $\begin{array}{l}\text { Sobre o Instituto de Belas Artese a } \\
\text { Universidade de Porto Alegre e a } \\
\text { posição da Feupa no episódio. }\end{array}$ \\
\hline 97 & & [citação] & Frase de autoria de Oscar Wide. \\
\hline $98 / 105$ & $\begin{array}{l}\text { Atos Gusmão } \\
\text { Carneiro, } \\
\text { Lelio Carvalho e } \\
\text { Paulo Távora }\end{array}$ & $\begin{array}{l}\text { A representação dos } \\
\text { estudantes nos } \\
\text { conselhos técnico- } \\
\text { administrativos. }\end{array}$ & $\begin{array}{l}\text { Sobre a participação dos estudantes na } \\
\text { administração da Universidade. Traz } \\
\text { comparações com pleitos estudantis e } \\
\text { características de universidades latino- } \\
\text { americanas. Apresenta a posição de } \\
\text { alguns professores em relação a esta } \\
\text { demanda. }\end{array}$ \\
\hline 105 & & Apoiado & $\begin{array}{l}\text { Elogios ao diretor da biblioteca pública } \\
\text { pela compra de mais livros. }\end{array}$ \\
\hline $106 / 112$ & $\begin{array}{l}\text { Engenheiro } \\
\text { Arnaldo Gladosch; } \\
\text { Leovigildo Paiva e } \\
\text { Luiz Leseigneur }\end{array}$ & $\begin{array}{l}\text { A construção da } \\
\text { Universidade de Porto } \\
\text { Alegre. }\end{array}$ & $\begin{array}{l}\text { Explanação da precariedade dos } \\
\text { prédios da universidade. Carta do } \\
\text { engenheiro ao prefeito e ao secretário } \\
\text { de educação sobre a construção da } \\
\text { cidade universitária. Sugestão de } \\
\text { aumento do campus central com um } \\
\text { grande edifício. }\end{array}$ \\
\hline 112 & & $\begin{array}{l}\text { [citação] } \\
\text { Gandhi, Mahatma }\end{array}$ & Citação texto de autoria H. Thomas. \\
\hline 112 & & $\begin{array}{l}\text { [citação] } \\
\text { A palavra e o homem. }\end{array}$ & Citação texto de James Joyce. \\
\hline $113 / 115$ & $\begin{array}{l}\text { Dr. Candal de } \\
\text { Santos } \\
\text { Professor de } \\
\text { Patologia Geral } \\
\text { (Medicina) }\end{array}$ & O Clube Universitário. & $\begin{array}{l}\text { Sobre as vantagens de se criar um } \\
\text { clube universitário. }\end{array}$ \\
\hline 115 & & $\begin{array}{l}\text { [citação] } \\
\text { Jesus. }\end{array}$ & $\begin{array}{l}\text { Citação texto de autoria de Ernest } \\
\text { Renan. }\end{array}$ \\
\hline 115 & & $\begin{array}{l}\text { [citação] } \\
\text { Dante. }\end{array}$ & $\begin{array}{l}\text { Citação texto de autoria de Henri } \\
\text { Thomas. }\end{array}$ \\
\hline
\end{tabular}

As últimas páginas da revista pertencem ao conjunto terceira parte: Ecos universitários. Nesta parte, os estudantes editores da revista apresentam seus feitos, obstáculos enfrentados e projetos. 


\section{Quadro 11}

Revista Feupa, terceira parte: ecos universitários.

\begin{tabular}{|c|c|c|c|}
\hline Página & Autor & Título & Assunto \\
\hline 117 & & Ecos universitários. & Sumário. \\
\hline $119 / 121$ & $\begin{array}{l}\text { Washington } \\
\text { Moreira }\end{array}$ & $\begin{array}{l}\text { Cooperativa } \\
\text { estudantil. }\end{array}$ & $\begin{array}{l}\text { Sobre as vantagens de se criar } \\
\text { cooperativas estudantis e sobre a } \\
\text { criação da primeira cooperativa. }\end{array}$ \\
\hline 121 & & $\begin{array}{l}\text { [citação] } \\
\text { O elogio de Lorca. }\end{array}$ & $\begin{array}{l}\text { Citação autoria não identifica. Versa } \\
\text { sobre um elogio feito por Frederico } \\
\text { Garcia Lorca a Pablo Neruda. }\end{array}$ \\
\hline 121 & & [citação] & $\begin{array}{l}\text { Versos escritos em francês de autoria } \\
\text { de Banave. }\end{array}$ \\
\hline 121 & & $\begin{array}{l}\text { [citação] } \\
\text { Por que? }\end{array}$ & $\begin{array}{l}\text { Citação de frase de autoria de Michael } \\
\text { Gold. }\end{array}$ \\
\hline $\begin{array}{l}123 / \\
125\end{array}$ & $\begin{array}{l}\text { Carlos Galvão } \\
\text { Krebs }\end{array}$ & $\begin{array}{l}\text { Apontamentos para a } \\
\text { História do curso } \\
\text { Gratuíto Mantido pelo } \\
\text { C. A. Franklin } \\
\text { Roosevelt. }\end{array}$ & $\begin{array}{l}\text { Sobre a história de um curso gratuíto } \\
\text { criado pelos estudantes para preparar } \\
\text { alunos do } 4^{\circ} \text { ano ginasial. }\end{array}$ \\
\hline 125 & & [citação] & Citação autoria de Monteiro Lobato. \\
\hline 125 & & [citação] & Citação autoria de Flaubert. \\
\hline $\begin{array}{l}126 / \\
129\end{array}$ & Osvaldo Teixeira & $\begin{array}{l}\text { A casa do estudante } \\
\text { do Rio Grande do Sul. }\end{array}$ & $\begin{array}{l}\text { Histórico sobre a criação da casa do } \\
\text { estudante. }\end{array}$ \\
\hline 129 & & $\begin{array}{l}\text { [citação] } \\
\text { Maneiras de } \\
\text { expressar-se. }\end{array}$ & $\begin{array}{l}\text { Citação pequeno texto de autoria de } \\
\text { Joyce. }\end{array}$ \\
\hline 129 & & [citação] & $\begin{array}{l}\text { Citação pequeno texto de autoria de } \\
\text { Charles Morgan. }\end{array}$ \\
\hline 129 & & [citação] & $\begin{array}{l}\text { Citação pequeno texto de autoria de } \\
\text { Luigi Pirandelo. }\end{array}$ \\
\hline $130 / 131$ & Edith Hervé & Teatro do Estudante. & $\begin{array}{l}\text { Sobre o teatro estudantil em Porto } \\
\text { Alegre e suas condições de ensaio e } \\
\text { produção. }\end{array}$ \\
\hline 131 & & $\begin{array}{l}\text { [citação] } \\
\text { Distância e o futuro. }\end{array}$ & $\begin{array}{l}\text { Citação de pequeno texto de autoria de } \\
\text { Goethe. }\end{array}$ \\
\hline 131 & & $\begin{array}{l}\text { [citação] } \\
\text { Fala Malagrida... }\end{array}$ & Versos em francês de R. P. Malagrida. \\
\hline 132 & & $\begin{array}{l}\text { Bureau de empregos } \\
\text { Departamentos de } \\
\text { informação e } \\
\text { Assistência Judiciária. }\end{array}$ & $\begin{array}{l}\text { Criação do departamento que fazia a } \\
\text { ligação entre os estudantes e as } \\
\text { empresas e o de assistência jurídica } \\
\text { para os estudantes. }\end{array}$ \\
\hline 133 & & $\begin{array}{l}\text { Eleições na } \\
\text { Federação dos } \\
\text { Estudantes } \\
\text { Universitários de } \\
\text { Porto Alegre. }\end{array}$ & $\begin{array}{l}\text { Sobre a primeira eleição direta da } \\
\text { Feupa. }\end{array}$ \\
\hline $\begin{array}{l}134 / \\
136\end{array}$ & & $\begin{array}{l}\text { Resenha estudantil de } \\
1945 .\end{array}$ & $\begin{array}{l}\text { Cronograma de fatos relacionados aos } \\
\text { interesses da Feupa ocorridos no ano } \\
\text { de } 1945 .\end{array}$ \\
\hline
\end{tabular}




\begin{tabular}{|l|l|l|l|}
\hline 136 & [citações] & $\begin{array}{l}\text { Quatro citações - Frases ou pequenos } \\
\text { textos dos seguintes autores: Goethe; } \\
\text { B. Ponce; Faulas e Camichael. }\end{array}$ \\
\hline
\end{tabular}

A universidade e seus problemas, assim como as demandas da vida estudantil, ocupam a maior parte das páginas de Feupa 1945/46.

Parecia-nos todavia, incompleta uma revista de estudantes que não abordasse o centro por excelência das atividades estudantis - a Universidade. Como uma das células da sociedade mais importantes no desenvolvimento cultural e formação de um povo, a discussão de seus problemas assume interesse marcante, projetando-se além do estrito âmbito da Universidade. (Feupa 1945/46, p. 6)

Uma bandeira defendida pelos editores de Feupa era a autonomia universitária, questão presente nos debates educacionais brasileiros desde os anos 1930. Segundo Veiga (1982), no Brasil da década de 1930, as pessoas ligadas à educação, identificadas com uma posição liberal democrática, defendiam que o ensino superior "tivesse liberdade de decidir sobre os aspectos considerados fundamentais para a instituição: estabelecimento do currículo, assignação dos recursos orçamentários, definição de

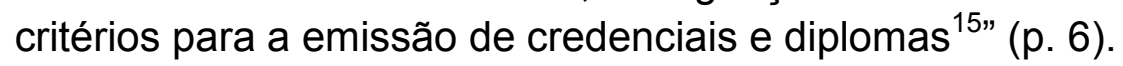

Se no Brasil o debate acerca da autonomia universitária e da participação discente nos conselhos universitários, na época, podia ser considerado recente, não podia se dizer o mesmo do restante da América Latina. Como os jovens editores de Feupa ressaltam (1945/46, p. 99-101), fora do Brasil, esta questão já tinha espaço há mais tempo.

Os estudantes divulgam o Congresso Nacional de la Federación Universitária Argentina e as decisões relativas ao "governo das Universidades de Córdoba e Buenos Aires" no ano de 1918 (Feupa, 1945/46, p. 99-100), assim como sobre os processos que definiram a participação discente nas decisões universitárias no Peru, Chile, Colômbia, México, Uruguai, Paraguai, Equador e Venezuela (Feupa, 1945/46, p.100-101) ${ }^{16}$. Estas ponderações auxiliam-nos a refletir sobre os processos históricos do ensino superior nas Américas espanhola e portuguesa. Podemos inferir que Feupa expressa preocupações do movimento estudantil da época:

No terreno das relações entre professores e alunos tomamos uma iniciativa com referência àqueles, de estreitar a tão decantada aproximação de mestres e discípulos, auscultando a opinião de alguns membros do corpo docente em questões que dizem respeito à vida da

\footnotetext{
${ }^{15}$ Ainda segundo Veiga (1982, p. 6), "contra essa concepção se contrapunham os herdeiros da tradição autoritária do Estado Novo, responsáveis pelo sufocamento das experiências da USP e da Universidade de Brasília do Distrito Federal no término dos anos 30. Os autoritários defendiam uma única estrutura universitária fortemente controlada pelo poder executivo central e órgãos como o Ministério da Educação e o Conselho Federal da Educação. Esta clivagem permeou todo conflito em torno da LDB desde 1947 e tivera sua expressão através de educadores como Anísio Teixeira e Fernando de Azevedo e os representantes do Estado Novo, tais como Francisco Campos e Gustavo Capanema".

${ }^{16}$ Os universitários participantes do movimento pró-autonomia e democratização do ensino superior indicam, nas páginas de Feupa, a leitura do livro Participación de los estudiantes em el gobierno de las universidades, editado pelo Centro Estudiantes de Derecho de La Prata, em 1942, de autoria de Gabriel del Mazo (Feupa, 1945/46, p. 101).
} 
Universidade. Nem sempre, é verdade, fomos felizes, mas como iniciadores resta depositarmos a esperança no futuro, às vezes tão pródigo em luzes esclarecedoras. (Feupa, 1945/46, p. 6)

O estreitamento das relações entre estudantes e professores é pensado como parte da idéia de participação estudantil nas decisões político-administrativas das faculdades e nas políticas educacionais:

Já decorreram 28 anos desde o histórico manifesto dos estudantes de Córdoba. Já na quase totalidade dos países latino-americanos, a direção dos institutos de ensino superior sofreu a renovação que o espírito da época e a realidade social estão a exigir. Plasmemos no estudante com mais firmeza, o espírito de responsabilidade por uma participação efetiva na administração universitária. Esta participação só poderá trazer vantagens a todos: o mestre conhecerá as opiniões do corpo discente; o aluno obedecerá com consciência de que colaborou na feitura do regulamento, com a satisfação de quem sente que a Universidade não é do Governo, é sua.Não estamos pedindo a concessão de nenhum favor; estamos é pleiteando um direito que de justiça é nosso! (Feupa, 1946, p. 105)

O movimento estudantil encontra-se presente, também, em menções sobre algumas de suas atividades ou preocupações como o $8^{\circ}$ Congresso Nacional dos Estudantes:

No VIII Congresso Nacional dos Estudantes foi ventilada a questão e entre as resoluções adotadas, temos a de n. 14 que reza: inclusão de 1 representante do corpo discente, eleito diretamente e com direito a voto, nos C.T.A. de cada Faculdade e de um representante da UNE junto ao Conselho Nacional de Ensino (Feupa, 1945/46, p. 99).

A $3^{a}$ Assembléia Democrática Estudantil do Rio Grande do Sul, realizada em Porto Alegre no ano de 1945, também esteve na pauta dos estudantes, assim como a greve dos estudantes de Engenharia, ocorrida no ano de 1945:

Os estudantes de Engenharia declaram-se em greve solidarizando-se com os demais colegas da Escola Nacional de Engenharia, em protesto, à deliberação ministerial que facultava a matricula nos cursos de Engenharia de ex-alunos de escolas militares sem exame vestibular. (Feupa, 1946, p. 134)

Fizeram parte das preocupações estudantis, além das questões de ordem política nacional presentes no contexto da época, o "pleito pela revogação de anuidade cobrada aos estudantes que contraria a gratuidade do ensino" (Feupa, 1945/46, p. 134), a "casa do estudante" (p. 126-129) e a "cooperativa estudantil" (p. 119-121).

Aliás, pensando no movimento estudantil da época e constatando as relações entre a Feupa e a UNE, podemos inferir que o dueto questões nacionais e problemáticas específicas do mundo acadêmico e estudantil caminhavam lado a lado, mas não sem tensões relativas á maior demanda de um ou outro aspecto.

Se o $2^{\circ}$ Congresso Nacional dos Estudantes, em 5 de dezembro de 1939, deliberou sobre a necessidade da participação dos jovens estudantes nos debates nacionais, com o 
tempo muitos universitários participantes de associações estudantis passaram a reclamar maior atenção para com suas necessidades acadêmicas e problemas cotidianos. Muitos passaram a questionar o que julgavam excessivas participações partidárias nos fóruns de suas associações. José Egydio, em depoimento à Araújo (2007, p. 81), afirma:

Outra coisa que a gente reclamava era que as teses de estudantes não eram tratadas. A tese nacionalista, "O petróleo é nosso" e outras, eram teses de política nacional. Mas a melhoria de ensino, tratamento mais direto ao estudante, não era tratada.

O exemplar disponível da Feupa deixa nítida a presença de diferentes posicionamentos políticos entre os seus colaboradores, assim como suas páginas denotam preocupações dos estudantes, da Universidade de Porto Alegre, tanto com as questões nacionais da época, quanto com as relações entre estes e a universidade: das 137 páginas, 46 se dedicam, exclusivamente, às preocupações com a universidade e com os estudantes.

\section{Considerações finais}

A publicação da revista pela Federação dos Estudantes Universitários de Porto Alegre fazia parte de um contexto escolar da época, em que era esperado que os estudantes produzissem periódicos. Estes eram, em grande parte, impressos ou patrocinados por órgãos públicos, como a própria Universidade, ou pelo órgão correspondente ao que seria hoje a Secretaria de Educação.

A participação nas associações estudantis, bem como na produção dos seus impressos, pelo menos neste período, pode ser pensada como uma iniciação, um aprendizado de participação na vida política do país. Podemos inferir este argumento a partir de dados levantados por meio de uma prosopografia, que está sendo construída sobre os estudantes nomeados nas páginas de Feupa 1945/46 e, também, a partir da contribuição de Paulo Brossard.

Em suas lembranças, Paulo Brossard traçou sua caminhada na vida pública brasileira tecendo-a como um prolongamento dos seus fazeres e escolhas diante das conjunturas vivenciadas desde os tempos de estudante universitário, assim como apontou outros casos de estudantes do curso de Direito, seus contemporâneos, cujas trajetórias também tiveram origem no meio estudantil. Vê-se que, além de Brossard, outros também seguiram a carreira política, tais como: Paulo Távora, Antonio Carapeto Fernandes, Eloar Guazelli, Carlos Galvão Krebs e Lenine Nequete. Sobre esse assunto é necessário aprofundar a pesquisa, entretanto já foi possível perceber influências da participação no movimento estudantil na constituição da vida política desses estudantes, assim como o uso da escrita na vida profissional de muitos deles.

Consideramos necessário refletir sobre as relações entre a política estudantil e as posições político-partidárias como referentes às políticas pensadas pelos grupos presentes nos poderes locais, estaduais e nacionais. Até onde os estudantes eram cooptados? Até onde transgrediam, reforçavam ou espelhavam o esperado pelos poderes reguladores? Até onde tinham autonomia? 
Em seu trabalho sobre a UNE, Araújo (2007) apresenta um exemplo de preocupações expostas acima quando aborda as relações dúbias entre o Estado Novo e os movimentos estudantis:

Durante o Estado Novo, o Brasil viveu um período de cerceamento das liberdades democráticas e de controle dos movimentos sociais, entre estes os movimentos estudantis [...]. O Estado Novo tinha uma grande ambição: a construção de uma identidade nacional brasileira [...]. Nesse projeto, a educação tinha um papel estratégico no preparo das elites que dirigiriam o país. E foi justamente o reconhecimento da importância da mobilização e da organização dos estudantes por parte do governo que produziu as tensões que marcaram as relações da UNE com o Estado Novo. (p. 35)

A Feupa e seu periódico de mesmo nome podem ser valiosos documentos para a pesquisa em História da Educação. Constituem-se em objetos ainda não explorados e guardam respostas a muitas perguntas que podemos lhes dirigir.

\section{Referências}

AMARAL, Giana Lange do. Gatos pelados $x$ galinhas gordas: desdobramentos da educação laica e da educação católica na cidade de Pelotas (décadas de 1930 a 1960). Porto Alegre: Ufrgs, 2003. 338f. Tese (doutorado em Educação). Faculdade de Educação, Universidade Federal do Rio Grande do Sul.

AMARAL, Giana Lange do. O Gymnasio Pelotense e a maçonaria: uma face da história da educação em Pelotas. Pelotas: Seiva/UFPel, 1999.

AMARAL, Giana Lange do. Os impressos estudantis em investigações da cultura escolar nas pesquisas histórico-institucionais. História da Educação, Pelotas: Asphe, n. 11, 2002, p. 117-130.

AMARAL, Giana; SILVA, Daiani Santos da. Aspectos da cultura escolar veiculados pelo impresso estudantil Complementarista da Escola Complementar de Pelotas/Rio Grande do Sul. ENCONTRO DA ASSOCIAÇÃO SUL-RIO-GRANDENSE DE PESQUISADORES EM HISTÓRIA DA EDUCAÇÃO, 11, 2005, São Leopoldo. Anais ... São Leopoldo: Asphe, 2005.

ARAUJO, Maria Paula. Memórias estudantis: da fundação da UNE aos nossos dias. Rio de Janeiro. Ediouro/Fundação Roberto Marinho, 2007.

BASTOS, Maria Helena Câmara. As revistas pedagógicas e a atualização do professor: a Revista do Ensino do Rio Grande do Sul (1951-1992). In: CATANI, Denice Bárbara; BASTOS, Maria Helena Câmara. Educação em revista: a imprensa periódica e a história da educação. São Paulo: Escrituras, 1997, p. 47-76.

BASTOS, Maria Helena Câmara. A Revista do Ensino do Rio Grande do Sul (1939-1942): o novo e o nacional em revista. Pelotas: Seiva, 2005.

CAMPOS, Eliane Pinheiro Medeiros. O ensino rural: uma discussão de especificidades. REUNIÃO ANUAL DA ANPED, 24, 2001, Caxambu. Anais ... Caxambu: Anped, 2001.

CARRA, Patrícia R. Augusto; PINEDA, Silvana Schuler. Mapeando a imprensa estudantil no Brasil de 1900 a 1964: um projeto de pesquisa em história da educação em uma escola de educação básica. ENCONTRO DA ASSOCIAÇÃO SUL-RIO-GRANDENSE DE 
PESQUISADORES EM HISTÓRIA DA EDUCAÇÃO, 11, 2005, São Leopoldo. Anais ... São Leopoldo: Asphe, 2005.

CATANI, Denice Bárbara; SOUSA, Cynthia Pereira de (org.). Imprensa periódica educacional paulista (1890-1996): catálogo. São Paulo: Plêiade, 1999.

CATANI, Denice Bárbara; VICENTINI, Paula Perin, LUGLI; Rosário S. Genta. O movimento dos professores e a organização da categoria profissional: estudo a partir da Imprensa Periódica Educacional. In: CATANI, Denice Bárbara; BASTOS, Maria Helena Câmara. Educação em revista: a imprensa periódica e a história da educação. São Paulo: Escrituras, 1997, p. 77-92.

COMPAGNONI, Ivo Carlos. História dos irmãos lassalistas no Brasil. Canoas: La Salle, 1980.

DESAULNIERS, Julieta B. Ramos. A formação via impresso. In: CATANI, Denice Bárbara; BASTOS, Maria Helena Câmara. Educação em revista: a imprensa periódica e a história da educação. São Paulo: Escrituras, 1997, p. 127-154.

DO Ó, Jorge Ramos. O governo de si mesmo: modernidade pedagógica e encenações disciplinares do aluno liceal (último quartel do século XIX meados do século XX). Lisboa: Educa, 2003.

FERRARI, Marcio. Condorcet: a luz da Revolução Francesa na escola. Disponível em: $<$ http://educarparacrescer.abril.com.br/aprendizagem/condorcet-revolucao-francesa-4511 11.shtml\#.> Acesso em: 10 nov., 2012.

REVISTA FEUPA, 1945/46.

FRANCO, Sérgio da Costa. Porto Alegre: guia histórico. Porto Alegre: Ufrgs, 1992.

LESSA, Luiz Carlos Barbosa. Prezado amigo fulano: meio século de correspondência (1950 a 2000). Porto Alegre: Alcance, 2005.

LETTI, Nicanor. O Centro Acadêmico e suas lutas. Disponível em:<http://antoniovalsalva. blogspot.com.br/2010/02/o-centro-academico-e-suas-lutas-num-4.html>. Acesso em: 14 out., 2012.

MENNUCCI, Sud. A crise de educação. São Paulo: Piratininga, 1934.

NEVES, Clarissa Eckert Baeta. Educação superior (1930-85). In: GOLIN, Tau; BOEIRA, Nelson (coord); GERTZ, René (dir.). República: da revolução de 1930 à ditadura militar (1930-85), v. 4. Passo Fundo: Méritos, 2007, p. 335-354.

NÓVOA, Antonio A imprensa de educação e ensino. In: CATANI, Denice Bárbara; BASTOS, Maria Helena Câmara. Educação em revista: a imprensa periódica e a história da educação. São Paulo: Escrituras, 1997, p. 11-32.

PINTO, Paulo Brossard de Souza. Entrevista a Dilza Porto Gonçalves e Patrícia Rodrigues Carra. Porto Alegre, $1^{\circ}$ out. 2012.

PINEDA, Silvana Schuler. Hyloea: o feminino na revista dos alunos do Colégio Militar de Porto Alegre (1922-1938). Porto Alegre: Ufrgs, 2003. 193f. Dissertação (mestrado em Educação). Faculdade de Educação, Universidade Federal do Rio Grande do Sul.

PRADO, Adonia Antunes. Intelectuais e educação no Estado Novo (1937-1945): o debate sobre a formação do professor primário rural. Teias, Rio de Janeiro: Uerj, v. 1, n. 1, 2000, p. 46-55. 
PRADO, Adonia Antunes. Ruralismo pedagógico no Brasil do Estado Novo. Estudos Sociedade e Agricultura, Rio de Janeiro, n. 4, 1995, p. 5-27.

PRATES, Paulo Roberto. A cirurgia cardíaca no IC-FUC. In: RODRIGUES, Rubens (org.). Do outro lado do rio: a história da cardiologia no Rio Grande do Sul. Porto Alegre: AGE, 2001, p. 76.

SKIDMORE, Thomas E. Brasil: de Getúlio a Castelo Branco (1930-1964). Rio de Janeiro: Paz e Terra, 1982.

SOUSA, Cynthia Pereira de. A educação pelas leituras: registros de uma revista escolar (1930-1960). In: CATANI, Denice Bárbara; BASTOS, Maria Helena Câmara. Educação em revista: a imprensa periódica e a história da educação. São Paulo: Escrituras, 1997, p. 93-110.

VEIGA, Laura da. Os projetos educativos com projetos de classe: estado e universidade no Brasil (1954-1964). Em Aberto, Brasília: Inep, v. 1, n. 10, 1982, p.18-30.

WERLE, Flávia Obino Corrêa. Escola normal rural no Rio Grande do Sul: história institucional. Revista Diálogo Educacional, v. 5, n. 14, 2005, p. 35-50.

WERLE, Flávia Obino Corrêa; BRITTO, Lenir Marina Trindade de Sá; NIENOV, Gisele. Escola Normal Rural e seu impresso estudantil. Educação em Revista. Belo Horizonte: UFMG, n. 45, 2007. <http://www.scielo.br/scielo.php?script=sci_arttext\&pid=S010246982007000100005\&Ing=en\&nrm=iso>. Acesso em: 4 set., 2012.

DILZA PORTO GONÇALVES é pesquisadora do Comitê da Transversalidade Governamental Seduc/Sedac-Figtf. Tem doutorado em História pela Pontifícia Universidade Católica do Rio Grande do Sul e trabalha com pesquisas relacionadas à história do Rio Grande do Sul, história da educação, memória, identidade e patrimônio.

Endereço: Rua Washington Luiz, 766/403 - 90010-460 - Porto Alegre - RS - Brasil.

E-mail: dpghistoria@hotmail.com.

PATRÍCIA RODRIGUES AUGUSTO CARRA tem graduação em História pela Universidade Católica Dom Bosco e em Estudos Sociais pelo Centro de Ensino Superior de Juiz de Fora. É estudante do curso de doutorado em Educação na Pontifícia Universidade Católica do Rio Grande do Sul e professora no Colégio Militar de Porto Alegre.

Endereço: Rua Dr. Dias de Carvalho, 325, casa 4 - 91910-270 - Porto Alegre, RS Brasil.

E-mail: profpatriciacm@gmail.com.

Recebido em 20 de setembro de 2012.

Aceito em 9 de fevereiro de 2013. 